\title{
Telecommunications Market Evolution in Finland and New Zealand: Unbundling the Differences
}

June 2008

\author{
Bronwyn Howell and Manisha Sangekar
}

New Zealand Institute for the Study of Competition and Regulation Inc. and Victoria Management School, Victoria University of Wellington, PO Box 600, Wellington, New Zealand. Email bronwyn.howell@vuw.ac.nz

Acknowledgement: The authors acknowledges the guidance, insights and helpful comments provided by Heikki Hämmäinen, V Sridhar and colleagues at the Networking Laboratory, Helsinki University of Technology, Päivi Peltola-Ojala and Petri Makkonen from Ficora, Osmond Borthwick from the New Zealand Commerce Commission and Glenn Boyle and Lewis Evans of ISCR. The Deane Endowment Trust funded Bronwyn Howell's sabbatical in Finland in 2007. Manisha Sangekar studied telecommunications regulation in Finland and New Zealand for a Victoria University of Wellington MBA research project supervised by Bronwyn Howell. The views expressed are solely those of the authors, and do not necessarily represent those of any ISCR member institutions. Any errors or omissions remain the responsibility of the authors. 


\section{Abstract}

Finland and New Zealand are two countries with many geographic, social, demographic and historic similarities. Their telecommunications markets also demonstrate many superficial similarities. However, beneath the superficial performance parallels lie two markets that have developed under fundamentally different cultural, institutional, commercial and political assumptions. By tracing the development of each market, this paper explores the effect that these differences have had upon shaping the markets and explaining both the observed similarities in market performance and the differences.

The comparative analysis suggests that Finland's industry characterised by decentralised and privately-owned local firms has adjusted to the more liberalised, commercially-focused and competitive markets in the $21^{\text {st }}$ century in a more measured and evolutionary manner than has been observed in New Zealand, where centralised government ownership and control prevailed until the revolutionary joint privatisation and liberalisation occurred. The different cultures, norms, values and attitudes observed in the two countries have both evolved as a consequence of the different market development paths taken, and in part explain many of the commercial differences. Nonetheless, the most significant differences in observed market performance appear to arise from regulatory artefacts - in New Zealand's case to the distorting influence of universal service and free local calling obligations, and in Finland's case to the prevention of mobile handset bundling with subscriptions. 


\section{Introduction}

To a casual observer, Finland and New Zealand share many similar characteristics. Both are countries on the periphery of their local geographic regions - Finland at the far north-eastern edge of Europe and New Zealand at the southern tip of the Pacific Ocean (Figure 1). Both are large (by European standards), sparsely populated countries characterised by specific geographic features (lakes in Finland; mountains in New Zealand) that pose challenges to the development of key infrastructures such as telecommunications, electricity reticulation and transport. Both are also dominated by a single large city of international scale (Helsinki in Finland; Auckland in New Zealand), but with several smaller regional centres and many local villages, and both rank nearly identically in their OECD urbanisation indicators. The similarities extend beyond the physical and demographic to a range of social characteristics (Table 1). Their small, open economies have likewise emerged from a common historical reliance upon primary production - notably the forestry industry and its downstream products (Frame, 2000).

\subsection{Political, Economic and Telecommunications Similarities}

The countries also share many historical political similarities. During the nineteenth century, both countries were ruled from abroad by a distant monarch, albeit with a local governorgeneral and a parliament with limited jurisdiction over local issues. From 1809 until gaining independence in 1917, Finland was governed from St Petersburg as an autonomous Grand Duchy of Russia, with its own senate based in Helsinki ${ }^{1}$. Contemporaneously, New Zealand was subject to British rule from London, successively as a territory of New South Wales, a Crown Colony (1841) with a local national parliament overseeing regional provincial governments from 1854 (provincial governments were dissolved in 1876) and as a selfgoverning Dominion from 1907. New Zealand did not assume full independence as a sovereign nation until adopting the Statute of Westminster in $1947^{2}$.

Both countries also share a tradition as avid and early adopters of electronic communications technologies (Table 2), a factor that may be attributable to the disadvantages of distance providing a greater spur to develop channels via which to communicate with the wider world (Poot, 2002). Telegraphy featured prominently in both countries in the nineteenth century, with Finland's first telegraph office being opened in Helsinki in $1855^{3}$ and New Zealand's in

\footnotetext{
${ }^{1}$ http://www.stat.fi/tup/suomi90/syyskuu_en.html?tulosta

2 http://www.nzhistory.net.nz/politics/milestones

${ }^{3}$ http://www2.hs.fi/english/archive/news.asp?id=20020403IE13
} 
Christchurch in 1862 (Wilson, 1994). Telephones, first successfully deployed for voice transmission in the United States in $1876^{4}$, were in operation by 1877 in Helsinki ${ }^{5}$ and Christchurch $^{6}$. Over time, Finland has been at the forefront of the Nordic countries in the number of telephone lines per capita and the deployment of new telecommunications technologies (Müller, et. al., 1993). Both countries deployed leading-edge networks early: fully digital networks (New Zealand in 1995 and Finland in 1996 - Howell, 2006), DSL technology (New Zealand June 1999; Finland May 2000 - OECD, 2005:13) and mobile telephony (NMT 4507 from 1982 and Radiolinja's world-leading GSM network from 1988 in Finland ${ }^{8}$, and Telecom's AMPS network in the late $1980 \mathrm{~s}^{9}$ ), with new telecommunications methods being widely available across the countries, despite the challenging terrain (e.g. DSL connections are available to $94 \%$ of New Zealand and 95\% of Finnish telecommunications consumers - OECD, 2007). By 2005, uptake of both fixed and mobile telephony in the two countries was practically identical: New Zealand had 43.6 fixed lines per capita and 101.9 mobile lines per capita, and Finland 43.4 and 102.7 respectively (OECD, 2007).

Both countries were also at the forefront of regulatory developments during the worldwide wave of telecommunication market liberalisation beginning in the 1980s (Spiller \& Cardilli, 1997). Initially each country adopted a unique, country-specific approach, but both have subsequently developed regulatory structures and obligations more consistent with the currently-prevailing European regulatory orthodoxy. Finland's regulatory regime has historically been characterised by extensive self-regulation and minimal political interference (Waverman \& Sirel, 1997), and was perceived as extremely 'light-handed', even by the notably liberal Nordic standards (Müller, et., al., 1993). This approach led it into conflict with the European Union, whose membership requirements mandated an industry-specific regulatory approach to which Finland has subsequently acquiesced (Pursiainen, 2003). New Zealand's variant of 'light-handed' regulation stems from its world-leading reliance upon competition law and contractual agreements to govern the telecommunications sector when, in the Telecommunications Act 1987, industry-specific regulation was eschewed (Boles de Boer \& Evans, 1996). New Zealand, too, has adjusted its regulatory stance over the past seven years to one more consistent with European Union mandates, again in part in response to a political desire for international regulatory conformity (Howell, 2007; 2008).

\footnotetext{
${ }^{4}$ http://en.wikipedia.org/wiki/Telephone\#Early_development

5 http://www.stat.fi/tup/suomi90/syyskuu_en.html?tulosta

${ }^{6}$ http://www.referenceforbusiness.com/history2/85/Telecom-Corporation-Of-New-Zealand-Limited.html

7 http://www.stat.fi/tup/suomi90/syyskuu_en.html?tulosta

${ }^{8} \underline{\mathrm{http}: / / \mathrm{www} . e l i s a . c o m / \text { english/index.cfm?t }=6 \& 0=6532.50}$

${ }^{9}$ http://www.referenceforbusiness.com/history2/85/Telecom-Corporation-Of-New-Zealand-Limited.html
} 


\subsection{The Differences}

However, the extensive superficial similarities mask crucial underlying differences. Closer examination of Table 1 reveals that whilst in 2004 18.8\% of New Zealand's resident population was born outside of the country, only 3.3\% of Finland's population was foreignborn. Moreover, Finland's population growth has been far less prolific than New Zealand's. Whereas Finland's population in 1900 was already nearly 2.7 million $^{10}$, New Zealand did not have one million inhabitants until 1908, and passed two million only in $1952^{11}$. Together, these facts suggest Finland's population has been far more stable and homogeneous (due to predominantly natural growth) than New Zealand's (which has expanded from a combination of immigration and natural growth).

There are also significant economic differences. Finland's GDP per capita, whilst similar to New Zealand's until the mid 1990s, by 2005 was approximately 20\% higher (Figure 2), due in large part to the Finnish economy's greater reliance upon industry (Table 3), particularly the ICT sector and a much larger share of economic activity coming from trade (Table 4). By contrast, using the gravity model, New Zealand is the world's most isolated industrial economy and is becoming relatively more isolated over time as, unlike most OECD countries, the share of trade in the economy is not increasing (Evans, 2007). Frame (2000:16) observes, in respect of Figure 1 and New Zealand's relative isolation: "the radii of the circles are the same. Within the circle centred on Helsinki there are 39 countries and approximately 300 million non-Finnish people. Within the circle centred on Wellington are Norfolk Island and a little of New Caledonia". Moreover, "if New Zealand sometimes feels that isolation is its defining characteristic, Finland's has been the opposite - a surfeit of sometimes prying neighbours” (p15).

Likewise, underlying the superficial telecommunications similarities are many other manifest differences. Whilst Finland has been at the forefront of the OECD in the number of broadband accounts sold per capita ( $8^{\text {th }}$, with 27.2 per 100 at December 2006 - OECD, 2007), New Zealand has languished in the lower third (by comparison $21^{\text {st }}$ with 14.0 per 100 at December 2006). Surprisingly, the large difference in uptake cannot be attributed simply to poor service quality or high prices in New Zealand. At the end of 2006, the average New Zealand price for a connection of $2 \mathrm{Mbps}$ or higher was nearly one third lower (in purchasing power parity terms) than the average Finnish charge (41 euro per month - Ficora, 2007:7). Moreover, whereas the basic New Zealand service offered to all customers in 2006 was 'best

\footnotetext{
${ }^{10}$ http://www.elisa.com/english/index.cfm?t=6\&o=6532.10

${ }^{11}$ http://www.stats.govt.nz/products-and-services/new-zealand-in-profile-2007/history.htm 
efforts' on a connection with a minimum capacity of 2Mbps, only 27\% of Finnish consumers subscribed to services of this quality or higher (Ficora, 2006).

The differences extend also into the fixed and mobile markets. Whilst Finland has been at the forefront of mobile telephony development, has some of the lowest prices in the OECD (OECD, 2007:217) and exhibits more than twice the number of call minutes per connection than New Zealand, in 2005 over 20\% of New Zealand's mobile connections were to leadingedge 3G networks whereas the comparable figure for Finland was less than 2\% (OECD, 2007:98). The low 3G purchase rate has occurred despite Finland being the first European country to license 3G operators (Pursiainen, 2003), a Finnish connection growth of 9\% (NZ's $12.2 \%$ ) and voice minutes per connection growing by $17.3 \%$ (NZ $4.2 \%$ ) over the period January 2005 to December $2006^{12}$.

In fixed line markets, whilst New Zealand's number of connections was relatively stable over the same period (a decline of 0.9\%), Finland's fell sharply (15.5\%). In addition to the decline in the number of fixed lines, the volume of chargeable call minutes per Finnish connection also fell more sharply (39.3\%) than the volume per New Zealand connection (12.7\%). Whilst the volume of chargeable call minutes per fixed line connection in each country is broadly similar (Figure 4), due to New Zealand's free local calling policy the total volume of fixed line traffic in New Zealand is approximately five times that of Finland ${ }^{13}$. New Zealand's high level of dial-up internet usage has been widely attributed to the absence of charging for local calls (Howell, 2007), but this charging approach has undoubtedly had a depressing effect upon the rate of substitution from dial-up to broadband internet access (Howell, 2008a).

\subsection{The Motivating Question and Research Methodology}

The interesting question posed by the juxtaposition of characteristics is: why, despite the very large number of outwardly similar characteristics, can two such countries end up with telecommunications markets exhibiting so many outward similarities but so many radically different inner differences? Why, for example, has New Zealand developed an extensivelyutilised fixed-line voice and dial-up internet network, but failed to transfer that usage to either mobile or broadband networks in the manner that has been achieved in Finland? And why, for example, has Finland, despite being a world leader in the development of mobile network

\footnotetext{
${ }^{12}$ New Zealand data sourced from Telecom Management Commentaries and Vodafone Quarterly Reports; Finnish ones from Ficora (2006).

${ }^{13}$ Telecom Management Commentaries up to 2003 indicate that only 21\% of the call volume was chargeable. Commentaries beyond 2003 cease documenting the ratio of charged to chargeable minutes.
} 
and handset technology, been unable to convert users from 2G to 3G technologies to the same extent and at an early stage in the network lifecycle as New Zealand?

In this paper, we address the primary question by starting with the proposition that market evolution occurs as a consequence of complex interaction between a number of factors: namely the technologies underpinning the market, policies governing interaction, and the actions of the participants in the market (Figure 5; Melody, 2005). As the interactions occurring are dependent upon previous actions and interactions that have occurred (Williamson, 1979; North, 1990), then differences in outcomes observed in the telecommunications markets of Finland and New Zealand in the twenty-first century likely have their genesis in interactions that have occurred in the past. As the actors, institutional arrangements, legal rules and cultures, norms, values and attitudes (Williamson, 1998; Koppenjan \& Groenewegen, 2005) have differed, then even though the technologies utilised in the two countries have been nearly identical, it is inevitable that different policies and market structures have developed. These different policies and market structures may serve to help explain why specific similarities and differences are now observed.

The paper proceeds as follows. In sections 2 and 3, we trace the history of the New Zealand and Finnish regulatory markets respectively, focusing upon the interaction between policy and industry participant responses. In section 4, we comment upon specific differences, and seek to use a comparison between the countries to find reasons why the different outcomes have emerged. Section 5 concludes with some suggestions about what each of the countries might learn from the other to inform current and future industry development.

\section{New Zealand's Telecommunication Market History}

New Zealand's telecommunications market genesis can be traced back to its nineteenth century colonial origins. Postal services in the territory were originally offered by a plethora of private companies, each charging their own individual rates for carrying letters and packages, with rates varying substantially for items carried over similar distances. One of the first acts of the newly-elected colonial parliament was, in 1856, to pass legislation enabling it to take regulatory control and ownership of the postal sector via the establishment of the national Post Office (Wilson, 1994:20). Following the very popular British 'penny post' model, the new government established a single, nationwide letter tariff, regardless of origin and destination. Competition with the government provider in the carriage of letters was legislatively foreclosed, but competition in the carriage of packages was permitted, notwithstanding the fact that the Post Office offered nationally-standardised weight- and 
distance-based rates for carriage of packages. Legislative protection of the Post Office persisted until deregulation in the 1980s.

\section{$2.1 \quad$ Telegraphy}

Telegraphy in New Zealand was initially undertaken by a mixture of provincial government and British military interests. The first telegraph lines were commissioned by the Canterbury Provincial Government in 1858 as a consequence of successful lobbying by local businessmen (notably the newspaper owners, who used their publications to rally popular support), but the link between Lyttleton and Christchurch did not begin operation until 1862 (Wilson, 1994: 28-28). The second was commissioned in 1860 by British military forces in Auckland province in anticipation of an attack by Waikato Maori. Following the defeat of the Waikato Kingite movement, the military asked the colonial central government to take over ownership and operation of the economically profitable line. The sale was transacted in 1866 at a price of £2,276 (Wilson, 1994: 29-30). Beginning in 1863, subsequent lines were deployed in conjunction with provincial government railway developments ${ }^{14}-$ in many cases preceding the actual railway construction as improved communications improved the ability to co-ordinate construction processes as well as being an essential component of the subsequent railway operations. Ultimately, many local railway stations became three-purpose depots, co-ordinating railway activities as well as acting as public post and telegraph offices.

The introduction of telegraphy was thus driven by specific commercial and strategic imperatives. However, from the outset a core element of the business case was the supply of messaging services to the general public. Government Post Office officials were quick to recognise the competition that telegraphy posed for their mail services, and in 1864 legislation was passed granting the Post Office full regulatory control of telegraphs. The political motivations cited were the desire to facilitate development of a nationwide telegraph system $^{15}$ and to encourage settlement in New Zealand's interior ${ }^{16}$. The office of Superintendent of Telegraphs was established under the Post Office umbrella, operating first in Christchurch and subsequently in Wellington. Consistent with the approach taken with postal services, one of the first regulatory actions undertaken was to mandate a single consistent national tariff schedule binding all operators, independent of their ownership form (Wilson, 1994:28).

\footnotetext{
${ }^{14}$ http://en.wikipedia.org/wiki/Rail_transport_in_New_Zealand\#Provincial_beginnings

${ }^{15}$ Postmaster-General, in the Department's Annual Report 1863 (Wilson, 1994:26).

${ }^{16}$ Wilson (1994:22) notes an intention of the Local Posts Act 1856 was to "establish a system commensurate with the rapid increase of population nationwide ... and to encourage and facilitate settlement of the interior”.
} 
When provincial government was disestablished in 1876, all provincial railway and telegraph assets reverted to central government control. The railway and telegraph assets were separated, with the railway ones being placed firstly in the Public Works Department and subsequently in 1880 the New Zealand Railways Department ${ }^{17}$ and the telegraph assets transferred to the Post Office under the control of the Superintendent of Telegraphs (Wilson, 1994:28). The Post Office thus became the monopoly owner and regulator of all postal and telegraph assets and service provision in New Zealand from 1876. The position of Superintendent of Telegraphs consequently rose substantially in status and importance within the Post Office. Wilson (1994) observes that the increased status and influence conferred was not lost on the incumbent at the time - Mr Charles Lemon - who proceeded to use his position to influence the development of industry strategy in a manner consistent with his own personal preferences and the relative advantage of the Post Office within the wider government context.

\subsection{Telephony}

Following the patenting of the telephone by Alexander Graham Bell in in 1876, New Zealand's first telephone connection was laid in 1877, linking Kaiapoi and Addington. A year later, the first commercial service, privately owned, began in Christchurch ${ }^{18}$. About the same time, an approach was made by the owner of the Melbourne Telephone Exchange to the Post Office to build an exchange in Wellington. Reputedly in response to this approach, the Superintendent prompted the Commissioner of Telegraphs to put a Bill before parliament precluding anyone other than the government from operating a telephone service in New Zealand without the permission of the Governor in Council. The relevant amendment to the Electric Telegraphs Act was passed and came into force in 1880 (Wilson, 1994:63). The arrangements conferred an effective government monopoly in both the connection and calling markets.

\subsubsection{Investment}

From 1880 until deregulation in 1987, the Post Office controlled all telephony investment and industry strategy. Government funding was sought via the normal political processes, whilst any private investment was also subject to Post Office and political sanction, as it had to be approved by the Governor, and such approvals could only be given if put to the governor by political agents on the basis of administrative recommendation. Initially, telephony was seen by the Post Office as a 'luxury' item. Early government investment was prioritised for

\footnotetext{
${ }^{17}$ http://en.wikipedia.org/wiki/Rail_transport_in_New_Zealand\#Provincial_beginnings

${ }_{18}$ http://www.referenceforbusiness.com/history2/85/Telecom-Corporation-Of-New-Zealand-Limited.html
} 
administrative and commercial purposes, and was therefore concentrated in central business districts and government-intensive locations Wilson, 1994:66). Although the vast majority of the population lived in rural areas and the economy was underpinned by primary production, "the state met the demands of rural telephony only when called upon to do so through the contract and petition system” (Wilson, 1994:71).

The contract and petition system established by the 1880 amendment required individuals wishing to pay for the installation of connections and exchanges themselves to put a case to the Post Office which would, if approved, be sent to the Governor for permission to be granted. Successful petitioners covered all the capital, installation and operating costs, but the equipment had to be procured, installed and operated by Post Office staff. All such 'petition' installations were subject to covenants specifying high sureties covering potential losses incurred by the government on procurement and installation, and that ownership of equipment would revert to the government in the event of any default in operating payments due to the Post Office. From 1899, in order to reduce the number of petitions received, only petitions made by a group of not fewer than six 'reputable' individuals were considered. Local authorities were expressly prevented from facilitating either the petitioning process or the installation of equipment until the passing of the Country Telephones Act in 1912. This Act granted local authorities permission to use ratepayer funds to supply wires and connect residents to Post Office exchanges.

By the 1920s, all connections and exchanges installed under the petition system had effectively reverted to government ownership (Wilson, 1994:70), typically under the terms of the covenants, or voluntary (uncompensated) surrender. As the individuals funding the initial connections had no ability to influence the operation of the assets they had funded, there was little benefit from maintaining any ongoing interest in the assets. However, the expectation that rural users and property developers would self-fund the laying of expensive connections to remote or new locations has continued, even under private sector ownership. Post Office, and subsequently Telecom, investment has been prioritised towards the provision of exchange and cabinet equipment, even though individuals continue to pay for the laying and maintenance of lines connecting their premises into the network, except where specified otherwise in line rental agreements.

\subsubsection{Tariffs}

The pattern of identical nationwide tariffs established for government-provided post and telegraph services was extended to government-provided telephones. Whilst initially based upon a complex set of factors including the length of the wire to the exchange, the duration of 
subscription and the order of connection to new rather than existing exchanges, line rental charges were simplified and standardised to a single tariff in 1883 (initially $£ 12$ per annum for the first year and $£ 10$ per annum thereafter, but by 1891 these had reduced to $£ 6$ and $£ 5$ per annum respectively).

From the very beginning, charging for calls between subscribers to the same exchange was eschewed. The Superintendent was not in favour of such charging as he considered it too “complex and onerous for exchange staff who would have to log the calls” (Wilson, 1994:66). Once the practice of 'free local calling' had become established, it was too politically difficult for the government-owned provider to alter the practice. Rather, as technology improved, allowing exchanges to expand, 'free local calling' areas increased in line with the growing exchange catchments. Ultimately, the establishment of 'free local calling' zone boundaries was decoupled from technological considerations, becoming determined solely by political fiat.

As the Post Office was the monopoly provider of all of connections, local and long distance calling, the books were able to be balanced by recovering losses on local calling and line rental subsidies from long distance and international revenues. Indeed, political support for increasing long distance charges was frequently garnered by trading off the increases with an increase in the size of 'free local calling' areas. As long as increased revenues at least covered revenues foregone, such a strategy was fiscally neutral. Whilst inevitably the tradeoffs must have at times had negative consequences, the lack of transparency in Post Office accounts made it difficult to ascertain the full extent of subsidy occurring, either within the telephony system itself, or from other sources such as Post Office postal or banking services or even the government funding vote (Wilson, 1994:151-3).

\subsection{New Zealand Industry Culture, Norms Values and Attitudes}

The patterns of government ownership, investment and tariff setting prevailed largely unchanged through most of the twentieth century. Commercial considerations were suborned to bureaucratic, administrative and political processes. Technological strategy was determined by a small number of senior managers within the Post Office. Investment was subject to these managers being able to elicit financial support from The Treasury and politicians, amidst a host of other calls on the government purse strings and political priorities. The small size of New Zealand and the political imperatives resulted in an episodic investment pattern that typically saw the entire network upgraded as a consequence of a single political decision, rather than incremental changes across time as a consequence of 
changes in the financial, commercial and technical environment. This investment pattern resulted in substantial technological standardisation (e.g. McTigue (1995) comments that even in the early 1980s, only one handset model in two colours was available) but a very 'lumpy' investment pattern. The last such 'lumpy' investment under government ownership was the decision taken in 1985 to fully digitalise the network (completed in 1995, when the firm was in private hands). Current plans announced by Telecom in 2007 to roll out a "Next Generation” fibre-based network in all exchanges serving 300 or more lines by 2012 reinforces the continuation of lumpy investment patterns.

Nonetheless, under government ownership, politicians utilised their position to affect the distribution of investment and activities in a manner that suited their own electoral purposes. Following the 1930s depression, the Post Office (along with other government services such as Railways and Public Works) increasingly became a means via which welfare benefits were distributed: for example discounted line rental charges for specific groups (e.g. the elderly), provision of more apprenticeships than the organisation could reasonably require to meet its future needs and employment of more staff than necessary to deliver services efficiently as an alternative to paying unemployment benefits. Customers, with no commercial power to alter industry outcomes, were restricted to political lobbying to effect any changes.

The consequence of such interactions was a culture of complete politicisation of the telecommunications sector. In terms of Figure 5, technologies could affect the New Zealand market structure only inasmuch as policy could be changed to reflect their presence. Likewise, customers could only affect their individual outcomes by influencing policies. In terms of the Williamson/Koppenjan, \& Groenewegen model, as government controlled both the policy and service delivery aspects of the market, in the absence of a clear separation of regulatory and service delivery powers, control of the sector rested with those making and enforcing the legal rules. They determined the identity of the actors, the shape of the institutions, and thereby influenced the evolution of the sector's cultures, norms, values and attitudes.

The cultures, norms values and attitudes thus came to reflect an industry with a single, strong, powerful political provider making all rules and decisions, and dispensing all services and benefits. The provider's position could be altered by comparatively powerless individual and institutional actors only by penitential pleading or the replacement of the incumbent powerholder/rule-makers by a coalition of alternative power-holder/rule-makers, who would act differently, but still wield the same power. The prevailing industry culture was one of centralised power and adversarial conflict. But whilst politicians came and went, senior Post 
Office officials entrenched in the same political processes were more permanent features. Given their long tenures, and public choice theory suggesting that such individuals will likely act in a manner that reinforces their own position, it is not surprising that the cultures, norms, values and attitudes associated with Post Office power established in the early days of the postal service in the 1850s and reinforced by Lemon's monopolising of the telephony networks for the government remained largely intact in the latter quarter of the $20^{\text {th }}$ century.

\subsection{Market Liberalisation}

New Zealand's market liberalisation began in 1984 with the election of the fourth Labour Government. Contrary to previous regimes and expectations of public choice theory, the new government embarked upon "one of the most notable episodes of liberalization that history has to offer” (Henderson, 1995 cited in Evans, Grimes, Wilkinson \& Teece, 1996: 1856) when it enacted economy-wide reforms based upon "stable, credible and mutually consistent macroeconomic policies which would assist in the efficient allocation of resources" and a microeconomic policy "achieving, wherever possible, a competitive environment in which markets can operate relatively free from subsequent intervention by government” ( $p$ 1863).

\subsubsection{Corporatisation and Privatisation}

As part of the reform process, the Post Office postal, banking and telecommunications services were separated into distinct, independent operational units. Telecommunications policy was separated from operational functions. Given the small size of the New Zealand economy, and the high costs of industry-specific regulation, generic competition law was favoured as the main restraint upon firms with a dominant position (MoC/Treasury, 1995). The Commerce Act, with a provision for price-setting in the case of dominant firms if this was seen as necessary (Section IV), was passed in 1986. The Telecommunications Act 1987 removed all statutory protections from competition that the government had enjoyed since the passing of the Electric Telegraph Act amendments in 1880, but created a range of reporting, disclosure and other regulatory obligations on firms that would be overseen by the Ministry of Commerce (later the Ministry of Economic Development).

The Telecommunications Corporation of New Zealand (Telecom) was established as a fully commercial stand-alone State-Owned Enterprise facing full competition on 1 April 1989. The sole additional regulatory instruments imposed were disclosure of discounts offered in excess of $10 \%$ of listed prices and a requirement to furnish specific information regularly to the Ministry of Commerce. 
Telecom was sold in its entirety to private interests for $\$ 4.25$ billion on 12 September 1990 (since listing in 1991, Telecom has comprised between $21 \%$ and $25 \%$ of the total capitalisation of the New Zealand stock exchang $\mathrm{e}^{19}$ ). In addition to the reporting obligations, the sale entailed the creation of a 'Kiwi Share' binding the private owners to cap residential line rentals, thereby preventing them from rising above the Consumer Price Index-adjusted level at the time of sale (the 'price cap' obligation), to ensure that rural residential line rentals would not exceed urban rentals (the 'universal service' obligation) and to continue to offer a residential tariff with no local calling charges (the 'free local calling' obligation) (Boles de Boer \& Evans, 1996). Thus, whilst ownership and locus of regulatory responsibility changed, the two regulatory pillars prevailing since 1880 - 'universal service' and 'free local calling' persisted, albeit in contractual rather than legislative form, and still underpinned by politically-motivated social distribution imperatives.

\subsubsection{Competitive Entry}

Competitive entry emerged rapidly. Clear Communications (subsequently merged with Telstra-Saturn to form TelstraClear) entered the long distance market in 1991, and by 1996 had achieved a $20 \%$ market share in national long distance and $25 \%$ in international calling (McTigue, 1998:36). Many other long distance providers have subsequently entered. BellSouth (subsequently sold to Vodafone) began services on its GSM mobile network in 1992, competing with Telecom's mobile AMPS service (subsequently replaced with TDMA and CDMA networks) provided since 1987. CityLink began providing Ethernet LAN services in Wellington in 1995, iHug offered nationwide satellite broadband services from 1998 and Saturn entered the cable television, broadband and telephone markets in Kapiti (subsequently entered in Wellington and Christchurch) in 1999 (Howell, 2003). Despite widespread entry, Telecom remained the dominant fixed line provider (over 95\% in 2003), but struggled to gain a share greater than $50 \%$ in the dial-up ISP market (Howell, 2003). Whilst Telecom was initially the market share leader in mobile services, Vodafone passed Telecom in May 2003 and since has maintained a small lead. However, it has not exceeded its peak share of 57\% in 2006 (Howell, 2007:64).

\subsection{The Road to Re-Regulation and Government Control}

Although sector ownership and the regulatory regime had instantaneously and irrevocably changed with the 1987-90 reforms, Telecom's position as the dominant participant in the sector, and the culture, norms, values and attitudes in which it operated, changed very little,

\footnotetext{
${ }^{19}$ Telecom is also listed on the Australian and New York exchanges.
} 
and if at all, very slowly. Whilst there is scant evidence of the firm having exerted its dominant position (none of the Section 36 court cases brought have ultimately found such actions have occurred), most industry participants interacted with the firm as though it was, like the old Post Office, actively wielding monopoly power. Interactions were thus largely adversarial and confrontational, rather than based upon commercial negotiation and cooperation. Virtually every strategic action taken by Telecom was popularly presumed to be deliberately anti-competitive. For example, when Telecom reduced local line rentals only in those areas where it faced infrastructure competition (a rational competitive action), it faced media accusations of predatory pricing. Similar accusations emerged when the Telecommunications Commission arrived at an internationally benchmarked price of $\$ 27.78$ for unbundled bitstream lines, compared to the firm's entry level broadband price of $\$ 29.95$, which had prevailed for at least two years prior to the bitstream service being mandated, and which was consistent with the long-term entry level prices of firms selling broadband connections on competing technologies (Howell, 2007).

In the absence of an industry-specific regulatory regime, claims of anti-competitive behaviour escalated into legal disputes that became subject to lengthy and confrontational court processes. The two most prominent were the dispute was between Clear and Telecom over the price of local interconnection (the 'Clear' case), which spanned three years and three court hearings, and the Commerce Commission's case brought in 1999 alleging Telecom's charging 2c per minute for residential dial-up internet calls made to non-Telecom fixed line numbers after the first 10 hours per month was anticompetitive (the '0867' case, after the calling prefix used), which was finally adjudicated in 2008.

\subsubsection{Competition and the 'Kiwi Share'}

At the crux of the Clear dispute was the extent to which Telecom could include in the interconnect price a margin to cover the additional costs of the social obligations embodied in the 'Kiwi Share"20. Whilst the Privy Council ultimately found that Telecom could legitimately include social costs in interconnection prices, the redistributive objective and political origins of the social objectives combined with the prevailing long-established industry culture, norms values and attitudes to make the court outcome a political issue. Although an inquiry by Treasury and the Ministry of Commerce in 1995 found no need to change the 'light-handed' regulatory arrangements, as the efficiency imperative was largely supported in the decision and industry-specific regulation was a costly alternative, a

\footnotetext{
${ }^{20}$ Clear Communications v Telecom Corporation (1993) 5 TCLR 166 (HC) 25, 27, 35, 103; Clear Communications v Telecom Corporation (1993) 5 TCLR413 (CA) 25; Telecom Corporation v Clear Communications [1994] 5 NZBLC 103, 552 (PC); [1995] 1 NZLR 385 (PC) passim
} 
perception prevailed that Telecom was continuing to act in the high-handed monopolist manner of its Post Office predecessor.

The perception of anti-competitive behaviour appeared reinforced by the '0867' case beginning in 1999. The Ministerially-approved charge was levied in response to competitors' arbitrage on an interconnect agreement that saw huge cash flows from Telecom to its competitors as a consequence of the rise of internet usage and the 'free local calling' obligation. These cash flows could potentially have bankrupted the company (Howell, 2007). Although the action was subsequently found not to be an anti-competitive exertion of a dominant position ${ }^{21}$, Telecom's competitors organised under the banner of the Telecom Users Association of New Zealand (TUANZ) responded with a public relations campaign and political pressure claiming that Telecom's actions were unilateral, anti-competitive and evidence of the 'failure' of the 'light-handed' regulatory regime, as it appeared to have militated against rather than facilitated competitive entry sufficient to diminish Telecom's dominant position.

\subsubsection{Political Processes Prevail}

Despite substantial fringe entry occurring (nineteen firms by 2003 - Howell, 2003), demonstrably lower real prices for fixed line rentals, long-distance and international calls, and a highly competitive ISP market with some of the highest uptake and lowest prices in the OECD (Howell, 2007), as a consequence of political petitioning, 'light-handed' regulation in general and Telecom's activities in particular became key subjects of the 1999 election campaign. The ultimately victorious Labour-led coalition government, as a means of distancing itself from its predecessor which introduced liberalisation and the subsequent National governments that succeeded it and maintained the liberalisation agenda, responded with a Ministerial Inquiry in 2000 that recommended industry-specific regulation be introduced $^{22}$.

The Telecommunications Act 2001 established the office of the Telecommunications Commissioner within the Commerce Commission, and gave the Commissioner the right to make determinations on price (using TSLRIC methodology) and non-price terms for a range of designated services sold by Telecom to competitors. Notably, full local loop unbundling and ADSL services were not included in the first round of designated services, as the Inquiry had found that infrastructure-based competition would emerge, and the 'Kiwi Share' was deemed to be an industry-wide charge (renamed the Telecommunications Service Order -

\footnotetext{
${ }^{21} 1732$ HRS Telecom Corporation of New Zealand Limited (NS)

${ }^{22}$ http://www.med.govt.nz/templates/Page 9159.aspx 
TSO) to be levied annually by the Commissioner on all market participants. The arrangements were intended to facilitate agreements only where parties were unable to agree, and "would still see New Zealand at very much the light-handed end of the regulatory spectrum, arguably the lightest within the OECD” (p 30).

In practice, however, an adversarial approach presuming Telecom to be perpetually exerting its dominance persisted. Rather than being, as originally intended, an arbitrator in respect of only a handful of disputed contracts, the Commission rapidly became the default forum for brokering every agreement between Telecom and its competitors (Howell, 2007). When the Commission recommended in 2003 that local loop unbundling not become a regulated service as the benefits were small and the risks to future imminent investment by Telecom in a Next Generation Network (NGN) were large, the decision was greeted with dismay amongst Telecom's competitors. Their immediate response was recourse once again to political petitioning ${ }^{23}$.

\subsubsection{Repoliticising}

Political petitioning has ultimately proved more decisive for the industry than remonstrations to the Commission, for both regulated (or potentially regulated) firms and their competitors. In the 2005 election, the Labour Party manifesto proclaimed "this Labour-led government has ended the destructive period of ultra-light handed regulation that stifled competition, growth and consumer choice in ICT markets" and promised to "closely monitor and enforce commitments made by Telecom New Zealand under the local loop unbundling decisions and ensure targets for broadband uptake for the next three years as outlined in the Digital Strategy are met” ${ }^{24}$. Upon re-election, the Labour-led minority government (holding a one-seat majority) immediately instituted a 'Stocktake' of the telecommunications sector, undertaken not by the politically-independent Commission, but by the Ministry of Economic Development - a policy agency with only limited industry-specific expertise accountable directly to the Minister.

An unscientific analysis based largely upon Telecom's competitors' unsubstantiated intentions to invest and a statistically flawed finding that competition factors (i.e. Telecom's dominant market share) best explained New Zealand's comparatively low broadband uptake (Howell, 2006) resulted in amendments to the Telecommunications Act mandating both full local loop unbundling and functional separation of Telecom's network provision facilities

\footnotetext{
${ }^{23}$ See, for example, iHug's submission to the Minister on the matter http://www.med.govt.nz/upload/5898/tcl-rsp-to-comcomllu-rpt-submission040209.pdf

${ }^{24}$ http://www.labour.org.nz/policy/jobs and economy/2005policy/Pol05-Comms/index.html
} 
from its other operations. Submissions were heard by politicians rather than regulatory personnel. Political trading associated with the maintenance of a stable minority government undoubtedly influenced the Act's passage through Parliament. Political considerations consequently overruled more reasoned analysis and commercial interests.

\subsubsection{Return to Political Control}

By 2007, resumption of full political control of sector strategy appeared to be complete. Despite the Commissioner twice recommending regulation of mobile termination rates, in April the Ministers of Communications and Economic Development instead rejected the Commissioner's recommendations and directly brokered a set of undertakings with the two firms concerned ${ }^{25}$. In May, the Minister of Communications announced that he, and not the Commissioner, would oversee the functional separation of Telecom ${ }^{26}$. It is noted that the vertically-integrated State-Owned Enterprise Kordia, via its subsidiary Orcon, is the only competitor to Telecom to have announced its intention to invest in every Telecom exchange unbundled. Telecommunications policy is again at the forefront of the 2008 election campaign, with the opposition National Party pledging to invest $\$ 1.5$ billion in a fibre-to-the home network, and the Labour-led government countering with \$350 million in contestable broadband funding in its May 2008 budget.

Whilst currently the vast majority of sector investment is privately held, New Zealand's industry direction is once again in political hands. However, unlike the vast majority of the sector's history of government ownership, the current exercise of political control is constrained by neither a substantial public ownership interest nor the long-term strategic view of the industry held by previous Post Office managers. The ability of an informed regulatory agency to credibly advise on policy direction also appears to have been suborned to political preferences. The deep-seated New Zealand cultures, norms, values and attitudes inured to political control of sector strategy do not appear to have been able to adjust to the commercial realities of a market where ownership and control are devolved to commercial and regulatory actors rather than political ones. Consequently, the default when challenges arise has been to political rather than commercial solutions.

\footnotetext{
${ }^{25}$ http://www.beehive.govt.nz/ViewDocument.aspx?DoumentID=28525;

http://www.beehive.govt.nz/ViewDocument.aspx?DocumentID $=29126$

${ }^{26}$ http://www.beehive.govt.nz/ViewDocument.aspx?DocumentID=29595 


\section{Finland's Telecommunications Market History}

As with New Zealand's, Finland's telecommunications market has its origins in the nineteenth century when the country was ruled as an autonomous Grand Duchy of Russia. Likewise, the origins also lay in the telegraph industry.

Historically, the Telegraph Office of Finland (begun in $1855^{27}$ ) was controlled by Russian officials $^{28}$. When the first telephone service was installed by factory owner Johan Nissinen between the office and his shop on the corner of Annankatu and Eerikinkatu, Helsinki in December $1877^{29}$, and mechanic Daniel Johannes Wadén was taking orders for telephones manufactured to Bell's design from customers in Helsinki and the surrounding countryside, it was unclear who would take responsibility for administering the new service. The Finnish Senate seized the opportunity to assert its independence by taking the fledgling industry under its jurisdiction and granting itself the right to issue licences to prospective operators via the Telephone Declaration in 1886 (Pursiainen, 2003:15). Tsar Alexander III endorsed the decision $^{30}$, and the modern Finnish telecommunications market was born.

\subsection{From Telegraph to Long-Distance State Monopoly}

The consequence of the Senate's action was the functional separation from the industry's very beginning of local connection and long-distance calling. The Russian-owned telegraph service continued to provide long-distance messaging services for the public, and telegraphy remained the predominant means of long-distance time-dependent communication for the majority of the public until private telephones began to become widespread in the 1920s. As in New Zealand, telegraphy service development occurred concomitantly with railway construction. Upon independence in 1917, railway telegraph assets were taken over by the State railways and the balance by the Telegraph Office. At this time, railway telegraph assets substantially exceeded those of the Telegraph Office (304 offices as opposed to 76) ${ }^{31}$. The 1919 Telegraph Law conferred a state monopoly on telegraph services (Pursiainen, 2003:15).

In 1927, the Telegraph Office was merged with the Post Office to become the Post and Telegraph Office. From 1935, when the Post and Telegraph Office bought the equipment of a private long distance company, long-distance calls became largely a state monopoly. In 1994, post and telegraph/long distance telephony were separated, with the telephony

\footnotetext{
${ }^{27}$ http://www2.hs.fi/english/archive/news.asp?id=20020403IE13

${ }^{28}$ http://www.stat.fi/tup/suomi90/syyskuu_en.html?tulosta

${ }^{29}$ http://www.elisa.com/english/index.cfm?t=6\&o=6532.40

${ }^{30} \mathrm{http://www.stat.fi/tup/suomi90/syyskuu \_ en.html?tulosta} \mathrm{p} 1$

${ }^{31}$ http://www.stat.fi/tup/suomi90/syyskuu en.html?tulosta $\mathrm{p} 3$
} 
component becoming the $100 \%$ state-owned limited liability company Telecom Finland. In 1998, the name was changed to Sonera, and the firm was listed on the Helsinki and NASDAQ exchanges. Sonera merged with Sweden's Telia in 2002 to form TeliaSonera ${ }^{32}$.

\subsection{Dispersed Ownership of Local Connection}

By contrast, however, local telephony developed along a very different path. The Finnish Senate made an early decision to pursue a devolved, localised model of telephony development. From a fiscal perspective, the advantage of this approach was that all investment came from the private sector. There were no state subsidies. The by-product was sector development almost completely free of government involvement and hence political influence.

Multiple licenses were granted to build and operate local exchanges (Pursiainen, 2003; Nattermann \& Murphy, 1998), with the first beginning operations in Turku in 1881. The Helsinki Telephone Association (subsequently Elisa) began operation on 6 June 1882 with 56 subscribers $^{33}$. Whilst there was no explicit policy to do so, in practice the licences were granted to firms that mostly enjoyed a local geographic monopoly (e.g. a competing licence was granted in 1931 for Loviisa, resulting in the first operator withdrawing - Pursiainen, 2003:37). By 1938, there were 815 firms providing 150,000 connections (a third of which were managed by the Helsinki Telephone Association ${ }^{34}$ ), at an average size of only 180 subscriptions. Many small firms were operated from a local switchboard in the corner of a farm kitchen (Pursiainen, 2003:7). Although substantial merging and consolidation took place after World War 2, in 2007 there were still 49 firms providing fixed line connections (Ficora, 2007).

\subsubsection{Growth of Co-Operative Ownership}

The Finnish Senate had no preconceived view of the 'ideal' or 'preferred' institutional form of the licensee firms. Whilst some licences were granted to private for-profit firms and local municipal authorities, the most common institutional form that emerged was the local consumer-owned co-operative. In part, this occurred because tax laws at the time favoured co-operative asset ownership over other private ownership forms (Pursiainen, 2003:12, 20). However, for a relatively homogeneous population with already-established linkages, as long as the membership does not become too large, co-operative ownership offers a relatively low-

\footnotetext{
${ }^{32}$ http://www2.hs.fi/english/archive/news.asp?id=20020403IE13

33 http://www.elisa.com/english/index.cfm? $\mathrm{t}=6 \& \mathrm{o}=6532.30$

${ }^{34}$ http://www.stat.fi/tup/suomi90/syyskuu_en.html?tulosta $\mathrm{p} 2$ 
cost structure guarding against the risk of paying excessive profits to a third party as might occur under contractual purchase of services with natural monopoly characteristics (Hansmann, 1996). As telephony consumers were also the owners, any profits gained from overly-high customer charges were in effect owned by those from whom they were taken, so there was no private gain from charging prices in excess of costs. The main risk was that, as for all monopolies, in the absence of competition they were not run as efficiently as possible. Pursiainen (2003:20) notes that co-operative structures engendered a culture of pride in the local provision of services and the non-profit objectives of the firms concerned.

Consumers could join their local co-operative by buying a share equivalent to one line. Shares were continuously available. New share purchase furnished the capital for network creation and expansion. Shares were expensive (in the order of 500 to 1000 euro at 1990 levels), but could be traded, for example along with the sale of a property or to a prospective member, who could pay an additional charge to have the connection moved to another location. Connections could be purchased without a share, but incurred a fixed charge of around 200 euro and ongoing charges of the order of 50 to 100 euro per annum higher than those levied on shareholders (call charges were the same for all customers). Over time, the discounts offered to shareholders consistently outperformed the expected return from a longterm investment in a bank account (Pursiainen, 2003:23) (in the order of $10 \%$ to $15 \%$ per annum - Nattermann \& Murphy, 1998:766), making continued co-operative share ownership commercially viable until the emergence of mobile telephony and the internet in the late twentieth century.

Local share ownership meant that network development tended to occur in response to demand and locally-specific improvements in economic conditions instead of central government political priorities. It also enabled network growth in times when access to corporate debt capital was difficult or costly to acquire. Whilst co-operative share ownership risks lock-in (for example, ownership of shares that decline in value because they cannot be traded when there is a downturn in the local economy or the firm's technology is superseded by that of a competing firm), the risk is less the more stable is the local population. In this respect, Finland's comparatively stable and homogeneous population made it a good candidate for co-operative development of the industry.

\subsubsection{Local Tariffs, Governance and Self-Regulation}

Local ownership also meant that each co-operative levied its own unique charges (both for shares and services) in response to its own locally-specific costs. As the firms were fully selffunding, with the exception of Sonera in respect of its services in the far north of the country, 
they received no government subsidies so have not been used as vehicles of welfare distribution (Nattermann \& Murphy, 1998:765) Unlike New Zealand, there has never been a single nationwide 'postalised' tariff, and Finnish consumers have been inured from the very beginning of the industry to the fact that both connections and calls in rural areas will cost consumers more than in urban areas.

Localised telecommunications charging is consistent with wider Finnish social policy, where it is treated as equivalent to other social needs such as food, clothing, accommodation and health care. Consumers pay market prices, with low-income individuals receiving tax-funded financial support to enable them to purchase essential social goods and services from the private sector at the prevailing local prices. The burden of determining who should receive benefits and how those benefits should be distributed is deemed too difficult and costly, and an inappropriate activity to be undertaken be either a private firm or a state-owned enterprise engaged in competitive or contestable markets (Pursiainen, 2003:38). Whilst urban teledensity has historically been higher in urban than rural $\operatorname{areas}^{35}$, the differential charging policy does not appear to have had an undue effect upon national teledensity compared to other countries (Nattermann \& Murphy, 1998; Müller, et. al, 1993).

Locally-specific pricing has also performed an important function in the governance and management of the local co-operatives. Consumers faced strong incentives to monitor prices in neighbouring co-operatives, and apply sanctions upon managers who failed to satisfy shareholders that they were performing adequately. Dissatisfied owners also had the option of merging with a neighbouring co-operative if managers failed to respond to shareholder pressure. Thus, the co-operatives developed a set of self-regulatory mechanisms that facilitated takeovers, constrained prices and ensured comparable basic minimum standards of service prevailed, without incurring the overhead of a stand-alone regulatory agency. Benchmarking against the co-operatives for both price and service quality was also used by consumers to assess the performance of the small number of for-profit and municipal firms (Pursiainen, 2003:12). Unlike New Zealand, charges have always been levied for local calls. Again, benchmarking could be used to assess local call price performance of the large number of firms.

\subsubsection{Mergers and Mega-Cooperatives}

Over time, technological progress resulted in the minimum efficient scale of the telephone firms increasing. In addition, decentralised ownership resulted in open competition between

\footnotetext{
${ }^{35}$ http://www.stat.fi/tup/suomi90/syyskuu en.html?tulosta p 2
} 
equipment manufacturers, and therefore many different technical standards. Mergers and takeovers offered the opportunity to address both issues simultaneously. Consequently, mergers have been a feature of the Finnish industry since its outset. For example, stateowned Sonera acquired its large share of the northern Finnish market via mergers and takeovers (Pursiainen, 2003:9) whilst the Helsinki Telephone Association (subsequently Elisa) grew from a combination of natural growth and acquisitions ${ }^{36}$.

The emergence of the Telegraph Office (subsequently Sonera) and its expansion into the connection market beginning in 1917 and the growth of long-distance calling posed a strategic threat to the local companies. Sonera's business model allowed it to cross-subsidise connections from long-distance calling - something that the small local companies were less well-placed to manage. Given the large number of small firms, and their co-operative ownership structure, the logical strategic response of the small firms if they wished to compete with Sonera but retain their independence was to federate. The result was the formation of 'mega-co-operatives' with firms as members. Each firm undertook its own operations, but co-operated with others in respect of those activities that benefited them jointly, such as brokering interconnection agreements, standards-setting, and creation of joint venture companies to carry out new business (notably long-distance (Kaukoverkko), international (Finnet International) and mobile (Radiolinja) calling, and data transmission (Datatie) services), some of which included major customers as minority partners (Pursiainen, 2003:10). Importantly, the mega co-operative also provided industry self-governance functions. Nonetheless, the independent local ownership of the companies allowed the continuation of competitive rivalry that facilitated cost containment and service quality improvements.

The first mega-co-operative formed was the Association of Telephone Companies (subsequently renamed Finnet in 1996) in 1921. The Helsinki Telephone Association as the largest single firm took a leading role in the association. Over time, most of the small firms either joined the Association or were taken over by Sonera (Pursiainen, 2003:9). Consequently, the industry has developed with a strong overlay of competitive tension between the state-owned and private sector camps. Nattermann \& Murphy (1998:759) identify that the Association of Telephone Companies actively lobbied against expansion of the state's role in the industry, and was able to prevent planned nationalizations in 1931 and 1948. The public/private tension is attributed by Pursiainen (2003:12) with hindering any possibility of cartel-like arrangements developing, and thereby fostering the evolution of a

\footnotetext{
${ }^{36}$ http://www.elisa.com/english/index.cfm?t=6\&o=6532.30
} 
remarkably competitive industry - a danger that would have existed if, for example, only small co-operative firms as a single mega co-operative existed. Plurality in ownership structure combined with a political flavour derived from pride in independence from government influence has thus been a defining cultural artefact of the Finnish market.

\subsubsection{From Mega Co-operative to Limited Liability}

Whilst largely free of government involvement, the mega-co-operative Finnet was not immune to internal political forces. Co-operatives offer advantages when they represent the interests of relatively homogeneous parties, but become unstable when voting interests (one member, one vote) do not reflect commercial interests (Hansmann, 1996). The stability of the Finnet co-operative has therefore relied critically upon the alignment of the objectives of the larger and smaller firms (within Finnet, in the late 1990s the Helsinki co-operative (subsequently Elisa) had as many subscribers as all the other firms combined).

The emergence of mobile telephony and the internet placed significant stresses upon the cooperative structure. In order to invest in the new technologies, capital injections were required. Whereas fixed line telephony capital had been raised slowly over many years by selling new line shares, this model was not appropriate for the fast-developing mobile and internet markets, where it was far from clear that the necessary capital could be acquired in a timely manner from a very widely spread shareholder group. Whilst debt capital may have been available, the higher risks associated with co-operative ownership structures deterred potential lenders.

In respect of mobile technologies, Finnet initially addressed the capital 'problem' by creating a separate joint venture Radiolinja, where each co-operative, rather than its members, were the shareholders and shares were tradeable. However, the emergence of the internet created further stresses, as the fixed line companies needed access to capital to enhance their existing network structures - a different proposition not amenable to the joint venture solution adopted for mobile telephony. The institutional 'solution' to this problem is typically to 'demutualise' and allow consolidation of existing shareholdings, or to create new capital stock that can be sold to a new equity partner (Hansmann, 1996). In either case, the co-operative structure must be abandoned. When significant mega co-operative members abandon the co-operative structure, the federation's collaborative culture built upon homogeneity of member interests, objectives and underlying structures is liable to be undermined.

As the largest firm, the pressures upon Elisa to access capital to improve its networks for internet transmission were substantial. In 1997, Elisa converted into a for-profit company and 
listed on the Helsinki stock exchange. Share ownership and the right to a line were unbundled, and the company began distributing dividends ${ }^{37}$. Elisa subsequently acquired a significant stake in other listed companies such as Riihimäen Puhelin Oy and Heltel ${ }^{38}$, and took over some of the smaller co-operatives. Whilst Elisa was changing its ownership structure, Finnet was engaged in negotiations to restructure its joint ventures and strengthen the co-operative structure. Given the very different strategic directions being undertaken by Elisa and the remaining members, the mega co-operative could not continue. In 2001, Elisa and its associates seceded from Finnet and formed their own federation. Elisa subsequently bought out the remaining Finnet companies from major joint ventures, notably the mobile service provider Radiolinja. The remaining Finnet companies bought Elisa out of the national long distance venture (Pursiainen, 2003:10).

Following Elisa' secession, the remaining co-operatives reorganised as a new co-operative, also known as Finnet. However, the co-operative has continued to be unstable. Some firms subsequently seceded, to join with either Elisa or Sonera. The two larger companies have also acquired independent companies formed to compete with the established players (e.g. Elisa acquired Saunalahti in $2005^{39}$ ). In 2007 a further split occurred when a number of the larger members took over the mobile firm DNA (formed by Finnet after the Elisa secession resulted in the sale of Radiolinja) and converted it into a full service provider ${ }^{40}$. In 2008, the Finnet federation has reduced to 27 remaining members ${ }^{41}$, and has a very much smaller market share. The 2006 and 2007 market shares of the four main provider groups are in Table 5.

The effect of the successive mergers has been to bring about a near complete transformation of the Finnish industry from vertically separated network operators and long-distance companies each with a local monopoly but competing on benchmark performance into three (and potentially four) fully vertically-integrated providers competing nationwide over a range of products and services. In Finland, in the absence of government direction, commercial imperatives have led to competition between structurally or functionally separate firms giving way to consolidation and competition between vertically integrated full-service communications firms.

\footnotetext{
${ }^{37}$ http://www.elisa.com/english/index.cfm?t=6\&o=6531.20

38 http://www.elisa.com/english/index.cfm? $\mathrm{t}=6 \& \mathrm{o}=6531.10 \& \mathrm{did}=9842$

39 http://www.elisa.com/english/index.cfm?t=6\&o=6531.10\&did=9842

${ }^{40}$ http://en.wikipedia.org/wiki/Dna_Finland

${ }_{41} \underline{\text { http://www.finnet.fi/index.asp?language }=1}$
} 


\subsection{From Collaborative Self-governance to Industry-Specific Regulation}

The Finnish market development has resulted in a set of industry governance arrangements as unique as the ownership of the firms involved. The creation of Finnet in 1921 led to the organic development of a body well-suited to providing not just a self-governing regulatory framework, but also a mechanism via which the firms could commercially interact with each other. This is well-illustrated by the development of novel interconnection agreements amongst the operators (Waverman \& Sirel, 1997).

\subsection{1 'Peering' and 'Sender Keeps'}

Rather than operators adopting end-to-end pricing to the consumer and then purchasing other call segments from the relevant operators via bi-lateral or regulated interconnection and call termination agreements as prevails in almost all other telecommunications markets, in Finland a 'peering' arrangement, where incoming traffic was handled at no charge to the originating operator, was adopted. The originating firm billed the originating customer and kept all proceeds (Pursiainen, 2003:26). As long as traffic between firms was approximately symmetric, the arrangement was relatively stable and low-cost, as it overcame the need for each firm to have a separate contractual agreement with each of the other up to 814 local firms and multiple long-distance providers (indeed, it is the charging model subsequently used in the emergence of the internet market, for precisely the same pragmatic desire to reduce contracting costs amongst a large number of providers who do not necessarily find it easy to enter into multiple bilateral contractual arrangements).

Even with the rise of long-distance calling and the emergence of Sonera as the near-monopoly long-distance provider, the 'peering' arrangements (alternatively known as 'sender keeps' or 'bill and keep') remained largely intact. Neither the local operators nor Sonera accepted that the other party should have the ability to influence the retail call price of their services. Both parties therefore set their own retail prices. The originating operator set a price that covered call initiation and plus a margin to reflect the costs of incoming calls handled and Sonera set the charge for the long-distance segment (Pursiainen, 2003: 24). The originating operator invoiced all charges and settled monthly with Sonera, retaining a small (agreed) proportion of the Sonera charge to cover bad debts (Pursiainen, 2003: 27).

\subsubsection{Mobile Changes}

The growth of mobile calling, however, put the peering arrangement in jeopardy as mobile traffic was not well balanced (mobile was used more for outgoing than incoming calls - the 
same tension that is now threatening peering agreements amongst internet providers as applications such as IPTV change internet traffic distribution patterns).

In 1994, the operators agreed to a variation of the previous peering arrangement, whereby the originating operator charged a local access fee covering both the originating and terminating segments of fixed calls and calls to mobile phones. Standardised, nationwide termination charges independent of operator costs or identity were agreed for fixed and mobile calls. Local operators billed customers local call charges, plus the relevant long-distance fee or standardised incoming mobile call charge depending on the call destination. Termination charges were paid by the originating operators to the long-distance and mobile operators, who acted as acted as clearing houses, paying balances on a monthly basis to the terminating companies. Like the previous arrangements, this system too was simple and self-regulatory, with the local call charge acting as a termination price ceiling. Furthermore, as termination charges were paid from local call charges, the system maintained the principle of keeping local charges fully separate from long-distance charges. In practice, termination charges were set at approximately half the average local call charge, as too-high a charge would have resulted in too little revenue for originating local operators (Pursiainen, 2003:26).

\subsubsection{EU Intervention}

However, the Finnish arrangements failed to meet the European Union requirements (developed in countries where there were only a small number of vertically-integrated network operators providing long distance as well as access services) requiring each network operator to set termination charges based upon its own specific costs, and requiring terminating charges to be included in long-distance charges where applicable. Meeting EU mandates removed the self-regulatory features of the Finnish system and imposed a layer of transaction costs for the firms and the regulatory body Ficora in establishing and justifying firm-specific charges that had not been necessary previously. Co-operative members were forced to abandon collaboration over interconnection and become commercial opponents. The intervention also blurred the boundaries between operators and their charges. Interconnection tariffs and retail charges immediately increased, in some cases doubling, requiring even more regulatory activity (Pursiainen, 2003:27).

It is debatable how much, in practice, the modified Finnish arrangements actually differed from the internal processes of a single firm with multiple exchanges averaging its costs across a large number of exchanges to arrive at a firm-specific charge for interconnection, or a regulator mandating a single price for interconnection to calls terminated at multiple exchanges each with their own unique termination costs. The EU arrangements appear to 
penalise the Finnet companies for their federated structure without considering the benefits of benchmark competition that are not available in markets where a single large firm dominates. It cannot be discounted that the increased transaction costs imposed in meeting EU obligations have been a factor in the ongoing merger activity and instability within Finnet. However, whilst mergers will reduce costs and regulatory overheads by reducing the number of contracts and interconnection prices, the consequence is an effective reduction in the number of firms and hence the quantity of cost-related benchmarking information that has played such an important role in supporting the Finnish tradition of light-handed regulation and wherever possible industry self-governance.

\subsection{Government Regulation and Market Liberalisation}

Historically, Finnish government policy and regulatory activity has been more in the form of granting permissions and facilitating the competitive and co-operative processes that have emerged than restraining dominant parties and becoming directly involved in arbitrating disputes and determining contractual prices and terms. Until 1994, regulatory powers lay with the office of Posts and Telegraphs. Following market liberalisation in 1994, in accordance with European Union principles, legislative and regulatory powers have been shared between the Ministry of Transport and Communications, which formulates policy and issues licences, and the stand-alone regulator Ficora, which administers industry-specific regulation (Pursiainen, 2003:15-16). However, as there were already many of the hallmarks of a competitive industry in Finland, liberalisation has focused mostly upon removing competitive barriers created by existing licences, and enabling greater access to facilities rather than price setting.

\subsubsection{Liberalisation}

The most notable Finnish licence laws were the original right to issue licences in 1886, the Telegraph Law in 1919 conferring a monopoly in this service on the government and the Telecommunications Law in 1987 enabling competing licences to be granted with political discretion (thereby facilitating the development of a competitive mobile market - previously only Sonera had been able to legally offer mobile services) (Nattermann \& Murphy, 1998). The first competing licence for GSM services was granted in 1990 (Pursiainen, 2003:20). Full competition in fixed line long-distance calling markets was enabled with the creation of Sonera in 1994. Within months, the Finnet companies achieved a market share in excess of 50\% (Natterman \& Murphy, 1998). Two other significant pieces of legislation were the Telecommunications market Law 1997 which (amongst other elements) required operators to lease lines to their competitors (i.e. open access and LLU) and the Communications Market 
Law in 2002 which created a technology-neutral environment by placing all communications services (including broadcasting, but excluding content) under the same legislative obligations (Pursiainen, 2003:15).

The consequence of its combined co-operative and predominantly privately-owned multioperator background is a modern Finnish telecommunications policy that relies strongly on market forces rather than regulatory intervention. Regulatory intervention is seen as a last resort rather than a first recourse. In most cases, the mere creating of a power to regulate has been sufficient to deter undesirable actions (likely as a consequence of the relatively limited extent of government involvement historically). The policy approach is underpinned by Finland's own experience and that derived by observation of other countries that "politically acceptable alternatives may well exclude useful and competitive alternatives ... Regulation should not prevent such development by mandating regulator-selected solutions or otherwise neglecting different competing solutions” (Pursiainen, 2003:33). This approach has been widely attributed as a significant factor in Finland's status as an early adopter of new technologies (Pursiainen, 2000), and its' potential as a 'test bed' for new products and services that might otherwise incur regulatory attention in other jurisdictions (a status also enjoyed by New Zealand until recent heavy regulatory interventions were mandated).

\subsubsection{Ficora the "Lazy Regulator"}

A feature of the Finnish approach, most likely deriving from the co-operative days, is the extent to which consultation and collaboration amongst the policy-makers and industry participants has underpinned the development of regulations. Quite unusually, with a few notable exceptions, there are no regulated tariffs.. Rather, the focus is upon providing information. Tariffs must be separated into their connection, rental and usage components. Ficora's role is to review the tariffs, and to intervene only if there is evidence that they deviate from cost-based principles. Moreover, Ficora takes no active part in negotiations between firms (e.g. in determining access prices). Whilst Ficora been described as a "lazy regulator" (Pursiainen, 2000:1) in adopting this approach, the consequence is relatively lowcost regulation and strong incentives for the firms themselves to determine acceptable prices, terms and conditions in the first place.

One notable exception requiring regulatory intervention was the EU requirement that interconnection prices be cost-based in respect of each individual fixed-line firm. The mandate broke apart the industry tradition of co-operation and self-regulation, leading to price increases which in some cases were double the previous charges. However, rather than regulating individual prices, the 'solution' was to institute a temporary price ceiling of $60 \%$ of 
local connection charges. Since the expiry of the mandatory ceiling, intervention has been on a case-by-case basis where Ficora has not been satisfied that the charges meet cost-based criteria (Pursiainen, 2003:34). Similar processes attend the assessment of charges for unbundled local loop access. These firm-specific charges remain the most contentious element of Finnish regulation, but the presence of many firms enables Ficora to have access to a rich base of information to benchmark prices and thereby guide its activities, in particular in establishinbg the thresholds at which intervention is indicated.

\subsubsection{Mobile Technology, Technology Neutrality and}

A key feature of Finnish policy is its objective of technological neutrality, encompassed in the 2002 Communications Market Law. Wherever possible, the laws apply to all technologies equally. The rapid expansion of mobile telephony has been in part attributed to this technology-neutral approach. Unlike other countries, but consistent with its original policy in granting fixed-line telephony licences, Finland has not charged mobile operators for spectrum licences. Rather, the rights have been allocated on the basis of a 'beauty contest' (Pursiainen, 2000:1). Whilst the risk existed that spectrum might not be used in a timely manner, or for the most productive purposes, this risk was to some extent mitigated by allocating the initial rights to two fiercely competitive groups - Sonera and the Finnet alliance. Subsequent allocations to smaller new entrants have facilitated rapid entry by fringe players, as they do not face spectrum cost entry barriers. The consequence is that Finnish mobile prices have been amongst the lowest in Europe.

However, technology 'neutrality' has not always been successful. In part to enable handset manufacturer Nokia to maintain its own profit margins and branding on handsets, until 2005 mobile network operators were precluded from bundling handset purchase with monthly account subscriptions (the other leading handset technology country South Korea has also used such rules - Kim, Byun \& Park, 2005). The consequence was a comparatively old handset stock and slow migration to new 3G technologies (Tallberg, et. al, 2007). With the removal of the bundling ban in 2005, the average handset age decreased substantially, and the diffusion and usage of $3 \mathrm{G}$ accounts has accelerated (Kivi, 2007).

\subsection{Finnish Industry Culture, Norms, Values and Attitudes}

As in New Zealand the Finnish industry had developed a set of cultures norms values and attitudes from its own unique historic origins, based around the pursuit of simplicity, commercial interaction, and co-operation between firms. This is reflected in its history of 
self-regulation, and the desire to proceed with a very 'light-handed' approach to governmentmanaged regulation.

However, this culture is not immutable, and poses some threats to the success of the Finnish industry. The usurpation of industry rule-making by EU mandates (evidenced in respect of interconnection) was likely as large a disruption to the Finnish industry as the liberalisation and privatisation of Telecom in New Zealand. The new arrangements pitted firms who had previously operated as peers against each other as rivals, in a manner to which they had not previously been accustomed. The role of long-distance operators as clearing houses was also undermined, as they now had to broker separate agreements with each of the local operators, and the trust that had previously existed could no longer be relied upon.

Fear was expressed initially that inevitably, commercial disputes would escalate into costly and litigious courtroom battles as has occurred in other EU regimes (Pursiainen, 2003:27) and in $\mathrm{t}$ the New Zealand experience. Nearly a decade on, however, these fears do not appear to have materialised. Rather, the response appears to have been characteristically and pragmatically Finnish. Although the formal rules may have changed, the ap[proach of the Finnish individuals, institutions (including regulatory bodies and Finnish rule-makers), cultures, norms, values and attitudes appear essentially unchanged.. The industry still appears to be characterised by the same principles of decentralised, industry-based decision-making, characterised by commercial interaction and co-operation where necessary in order to advance mutual agendas. Decentralised control and minimal government intervention has resulted in an industry whose strategy is driven predominantly by industry participants. Changes that have occurred have been incremental rather than revolutionary, and despite pressure to conform to European Union conventions, still bear the hallmarks of industry-wide co-operation to minimise the impact of 'prying neighbours' on Finnish ways. The Finnish industry continues to be able to adapt rapidly and innovatively to technological changes, albeit with the requirement that the regulators must account to the EU on elements of performance and adherence to EU directives. Whilst the risk exists that welfare-enhancing regulation may not be undertaken rapidly, in an era where technology is changing rapidly, on balance the sentiment is that the light-handed approach most likely results in gains from innovation exceeding potential losses from absence of regulation.

\section{Comparing Finland and New Zealand}

The two industry histories offer case studies of two diametrically opposed industry approaches leading to the development of diametrically opposed cultures, norms values and 
attitudes which in large part appear to have prevailed despite attempts over the past two decades to impose new sets of rules and institutional structures on established industry actors. Even when those rules and structures are relatively homogeneous in their nature, the responses in each country have been very different from each other, as the industry participants embodying the cultures, norms, values and attitudes that have shaped the industry in the past are the same ones charged with interacting under the new rules and structures and shaping the industry's future.

\subsection{Different Histories Lead to Different Cultures}

New Zealand's strongly centrally- and government-controlled industry deriving from colonial heritage and postal legislation imported from England echoes industry development in much of the rest of the world. This development stands in sharp contrast to Finland's decentralised industry where government's active participation was localised both geographically and with respect to market segments. A key difference appears to lie in the different approaches to property rights. Whereas both in rural New Zealand and most of Finland individuals seeking connection to the infrastructure paid for the assets, in Finland those who invested the capital retained a designated share in the ensuing business, whilst in New Zealand governance of the assets was subsumed into the wider political processes. The different assignment of these property rights appears to have had a significant part to play in the development of Finland's commercial culture and New Zealand's political one. Individual property rights engender a far greater sense of local ownership and participation in governance and self-regulation than communal rights (Milgrom \& Roberts, 1992; Hansmann, 1996; Megginso \& Netter, 2002). Finnish consumers owned their own shares and could act individually and collectively in a commercial manner with respect to their ownership interests. By contrast, New Zealand consumers were subject to both a collective ownership 'tragedy of the commons' and the dilution of their telecommunications interests amongst all other government activities. Deprived of a commercial means of interaction, the only recourse for New Zealanders was political.

In short, the prevailing forces in the development of the Finnish industry have been those of technological and market development, whereas New Zealand's has been dominated largely by policies. The Finnish industry's participants' longer experience and greater familiarity with private ownership and commercial principles governing sector interaction has resulted in a pattern of incremental changes driven by technological and commercial imperatives and building on and consolidating the prevailing commercial culture. This is in contrast to revolutionary changes in the New Zealand industry, which have resulted in perennial recourse 
to the prevailing culture of political intervention. Whereas Finnish liberalisation was largely comprised of the government exiting its historic ownership interests and refining an already light-handed regulatory framework governing industry participants with a history of over one hundred years of commercial interaction, the New Zealand industry was simultaneously privatised and liberalised into an environment where market participants had been conditioned to political interaction and lacked commercial experience.

The original intentions of the designers of New Zealand's regulatory regime were to create a light-handed environment that, as in the Finnish case, gave primacy to commercial interaction, and saw regulatory intervention as a last resort. Whilst the legislation and institutions specified such an environment (levels 2 and 3 of the Koppenjan \& Groenewegen (2005) framework), their incompatibility with the prevailing cultures, norms, attitudes and values (level 1) of the existing participants (level 4) resulted in tensions that ultimately resulted in substantial politically-motivated changes to the level 2 and 3 laws and institutions. By contrast, rather than being 'designed', the Finnish industry has evolved to its present structures, leading to gradual adjustment of the factors at all four levels of Koppenjan \& Groenewegen's (2005) framework. However, it has not been immune to externally-imposed changes - notably the obligations to adopt EU-mandated rules and institutional interactions at levels 2 and 3 - that have challenged the nature of industry interaction. Nonetheless, the history of constant and continual adaptation of the industry to commercially-induced change has meant that the Finnish industry has been more prepared to respond at the commercial rather than the political level to the challenges of EU regulatory harmony - for example, by further reorganising of the Finnet co-operative and the use by Ficora of contractual tools and processes rather than explicit price-setting and other ex ante regulations to moderate industry interaction.

\subsection{Different Histories Explain Different Market Performances}

The different industry histories thus explain in large part the different responses seen at the commercial and regulatory levels in Finland and New Zealand. But the question remains as to how these different paths may explain differences in some of the key performance indicators identified in Section 1.

\subsubsection{New Zealand's Low Mobile Usage and Broadband Uptake}

New Zealand's low broadband uptake compared to Finland appears to be best explained by the historic patterns of universal service pricing of residential line rentals and free local calling. These key elements of the New Zealand regulatory environment have been 
unchallenged since their implementation in the nineteenth century, and even in a privatised and liberalised environment, they have been too politically difficult to change (although a review is currently underway). Free local calling is responsible for PSTN traffic in New Zealand being five times that in Finland, simply because callers do not face the marginal cost of their usage (as any call with marginal value in excess of zero will be made, whereas in Finland only calls with marginal value in excess of the call charge will be made). However, the costs of calling must be recouped from other services - notably fixed line connection charges, which must be higher than if a per-call charge is levied. New Zealanders thus pay higher line rentals than Finns. Moreover, universal service charging means that urban consumers subsidise rural ones, and that the subsidy is bigger in the presence of free local calling.

As fixed line and mobile calling are close (but not perfect) substitutes, the presence of a noncharged fixed line voice call option in New Zealand must inevitably affect the volume of voice calling on the mobile networks. Hence, free local calling in large part would explain New Zealand's lower mobile call volumes. Even if mobile prices were identical, the lowercost partial substitute would mean fewer mobile call minutes in New Zealand. The difference is further exacerbated by higher call charges in New Zealand.

Universal service prices have also affected the rate of substitution from fixed line to mobile connections. In rural areas, the subsidy for fixed line rentals likely lowers the price to consumers below the cost of a mobile connection, thereby slowing the diffusion of rural mobile connections. Conversely, it may accelerate the rate of substitution in urban areas if the fixed line price is above mobile connection costs. However, in New Zealand, the bundle of both line rental and calling must be balanced in determining the optimal point of substitution from fixed to mobile. As the number of connections in both Finland and New Zealand is similar, it is difficult to assess the relative effect of the 'Kiwi Share' obligations on subscription numbers.

The relative uptake of broadband connections, however, is critically affected by both the free local calling and universal service obligations. As dial-up internet is a partial substitute for broadband, universal service subsidies affect the timing and location of investment in broadband infrastructure. Subsidies lower the price at which a user will purchase alternative broadband infrastructures - if the new technology has lower cost than telephony, but is higher than the subsidised price, investment that would be more efficient does not occur in rural areas. Conversely if urban users pay a price above cost, entry may be induced by new 
technologies that are less efficient than the incumbent's. In Finland, these problems are avoided as fixed line services are priced according to local costs.

Howell (2008a) illustrates that for existing dial-up internet users, free local calling results in a much later substitution to broadband than when the user pays the marginal cost of dial-up internet calls. Likewise, the greater the size of the line rental connection, the greater the benefit that must be achieved from internet use to justify the substitution from dial-up to broadband, as the extent of the 'connection gift' must be overcome. Higher fixed line charges (as occurs when universal service prices are embedded in line rentals) will lead to later substitution than in the case where there is no subsidy. Thus Finland, with locally-specific line rentals and charges for local calls would have experienced earlier substitution to broadband than New Zealand, despite the fact that New Zealand has a larger proportion of the population using the internet.

\subsubsection{G Mobile Handset Uptake}

Although fixed line telephony has been subject to industry-specific regulation in New Zealand, mobile telephony, which emerged and developed principally in the period of 'lighthanded regulation and once Telecom had been privatised, has been largely free of political intervention (except in respect of sale and purchase of spectrum and the recent Ministeriallybrokered termination agreement). Handset bundling (i.e. discounting the price of a handset and recouping the cost from subscription and calling charges, from the customer in question or even from calling revenues charged to other high-using customers) has been a feature of the New Zealand industry, in part because with two networks using different technologies, customer switching between networks induces additional costs in that a new handset must be purchased. By lowering the up-front cost of a handset, operators are able to lower explicit switching costs and increase switching behaviour. The same bundling strategy can be used to lower the up-front costs to users switching between different technology generations (e.g. when Telecom switched from TDMA to CDMA, or from 2G to 3G).

The key to successful bundling relies upon an internal welfare 'subsidy' between a product that the user values highly (e.g. calling) and one that is valued less highly (e.g. a handset with features not required, or when the existing handset is still functioning perfectly). In these cases, the user may purchase a handset in a bundle when one would not be purchased if offered separately at cost, because the surplus gained from calling 'subsidises' a notional loss of value from purchasing the handset. As it is generally agreed that demand for handsets is more elastic than demand for calling (ref), bundling handsets and calling packages will induce 
greater numbers of handsets to be purchased than when selling each separately at cost (Carlton \& Perloff, 2004).

New Zealand's high uptake of 3G handsets is most likely because of aggressive and highly targeted bundling behaviour in the market. Finland's lower uptake when handset bundling was prohibited, and the reduction in age of the handset stock when bundling was allowed, is consistent with the findings of low customer valuation of the handset relative to the value of calling and the predictions of the value of bundling in the wide diffusion of a new technology.

\section{The Lessons}

In conclusion, can be learned from the comparison to inform each country? The first lesson from Finland is that neither a single firm nor industry-specific regulation is imperative in the construction of new local public good networks. Co-operative ownership, with shareholdings, provides a viable alternative that engenders both consumer participation in governance and industry self-regulation and standards-setting, and the emergence of benchmark competition. The second Finnish lesson is that competition is antithetic to the principle of universal service pricing. Local prices must reflect local costs if efficient competition is to emerge. For example, operators of new, cheaper technologies can make local entry decisions based upon real not subsidised prices, bringing forward the time when inefficient incumbents can be ousted. Whilst the obvious example is the replacement of fixed line telephony by mobile in parts of modern Finland, the use of a competing licence to remove an incumbent in Loviisa in 1931 is also instructional. The third lesson from Finland is that a light-handed approach to regulation is feasible, but that it requires a consistent underlying industry culture of co-operation and trust to operate effectively. This includes very selective use by government of its regulatory powers in order to maintain the underlying culture of trust and co-operation, and the primacy of commercial interaction.

The main strategic lessons from New Zealand are that judicious bundling can accelerate the diffusion of new technologies - as evidenced by handset bundling - but that universal service and 'all you can eat' usage packages can delay the substitution from a legacy technology to a new one - as evidenced by the Kiwi Share distortions in the fixed line market. On an institutional level, the New Zealand example compared to the Finnish one reveals that it takes more than simply changing the rules and ownership of the institutions to develop a competitive market. Unless the rules and institutions are consistent with the norms, cultures values and attitudes of the actors involved, revolutionary change may lead simply to more revolutionary change, that is not necessarily consistent with the original objectives. Where a 
more measured approach is taken over time, and institutions, rules and actors can evolve alongside the industry, and cultures, norms, values and attitudes can adapt consistent with the evolutionary developments. The latter lesson stands as an insight for all countries attempting to adopt regulatory harmony by imposing a standard set of rules and institutions. As the Finnish and New Zealand comparison shows, unless the other elements are consistent, the result may be less rather than more harmony. 


\section{References}

Boles de Boer, D., \& Evans, L., (1996). The economic efficiency of telecommunications in a deregulated market: the case of New Zealand. Economic Record, 72(216) pp 24-39.

Carlton, D., \& Perloff, J., (2005). Modern industrial organization ( $4^{\text {th }}$ ed.). Boston: Pearson/Addison Wesley.

Evans, L., (2007), Reporting the economy: background to sustainability. Presentation given to the Journalists' Training Organisation Course, March 7, 2007. Available on http://www.iscr.org.nz/f287,7689/7689_le_070307.pdf .

Evans, L., Grimes, A., Wilkinson, B., \& Teece, D., (1996), Economic reforms in New Zealand 1984-1995: the pursuit of efficiency. Journal of Economic Literature 34 (December 1996), 1856-1902.

Ficora, (2007), Market analysis of the market for wholesale broadband access. Paper 1384/935/2006, 19.3.2007. Helsinki, Finland: FICORA.

Ficora, (2006), Market Review, Quarter 4 2006. Helsinki, Finland: FICORA.

Frame, D., (2000), Finland and New Zealand: a cross-country comparison of economic performance. Working Paper 00/1, The Treasury, Wellington, New Zealand. Available on http://www.treasury.govt.nz/publications/research-policy/wp/2000/00-01 .

Hansmann, H., (1996), The ownership of enterprise. Cambridge, Mass.: The Belknap Press of Harvard University Press.

Howell, B., (2008), The end or the means? The pursuit of competition in regulated telecommunications markets. Paper presented at the International Telecommunications Society $! 7^{\text {th }}$ Biennial Conference, Montreal, Canada, June 24-27, 2008.

Howell, B., (2008a), Regulated retail tariff structures, dial-up substitution and broadband diffusion: learning from New Zealand's experience. Paper presented at the European Association of Researchers in Industrial Economics conference, Toulouse, France, September 4-6, 2008. Available on http://www.iscr.org.nz/f402,11192/11192 reg ret tar_BH_180308.pdf

Howell, B., (2007) A pendulous progression: New Zealand's telecommunications regulation 1987-2007. Wellington, New Zealand: New Zealand Institute for the Study of Competition and Regulation. Available on http://www.iscr.org.nz/f378,10548/10548_Pendulous_Progress_v_4_12_Nov.pdf

Howell, B., (2006), Submission: Telecommunications Amendment Bill. Available from http://www.iscr.org.nz.

Howell, B., (2003), Building best practice broadband: bringing infrastructure supply and demand together. Wellington, New Zealand: New Zealand Institute for the Study of Competition and Regulation. Available on http://www.iscr.org.nz/f213,4379/4379_building_best_practice_060603.pdf

Kim, H., Byun, S., \& Park., M., (2004), Mobile handset subsidy policy in Korea: historical analysis and evaluation, Telecommunications Policy, 28: 23-42.

Kivi, A., (2007), Mobile Data Adoption in Finland 2005-2006. paper presented at the 6th Conference on Telecommunication Techno-Economics (CTTE 2007), 14-15 June, 2007, Helsinki, Finland.

Koppenjan, J., \& Groenewegen, J., (2005). Institutional design for complex technological systems. International Journal on Technology, Policy and Management, 2005, Fall, pp. 11-34.

McTigue, M. 1998. Alternative to regulation: a study of reform in New Zealand. Regulation 21(1), 34-40.

Megginson,, \& Netter, J., (2001), From state to market: a survey of empirical studies on privatisation. Journal of Economic Literature 39(2):321-389.

Melody, W., (2005), Regulation and network investment: a framework for analysis. Chapter 1 in Mahan, A., \& Melody, W. (eds) Stimulating Investment in Network Development: Roles for Regulators pp 19-38. Lyngby, Denmark: WDR Project, LIRNE.NET. 
Milgrom, P., \& Roberts, J. (1992). Economics, organization and management. Englewood Cliffs, New Jersey: Prentice-Hall.

Ministry of Commerce \& The Treasury. (1995). Regulation of access to vertically-integrated natural monopolies. Wellington, New Zealand: Ministry of Commerce; The Treasury.http://www.med.govt.nz/templates/MultipageDocumentPage_4560.aspx

Müller, J., Bohlin, E., Karpakka, J., Riis, C., \& Skouby, K-E., (1993), Telecommunications liberalization in the Nordic countries, Telecommunications Policy 17(8), pp 623-30.

Nattermann, P., \& Murphy, D., The Finnish telecommunications market: advantage of local access incumbency. Telecommunications Policy 22(9), pp 757-73.

North, D., (1990), Institutions, institutional change and economic performance. Cambridge, Massachusetts: Cambridge University Press.

Organization for Economic Co-Operation and Development (2007). Communications Outlook 2007. Paris: OECD. Available on http://www.oecd.org .

Organization for Economic Co-Operation and Development (2006). Information Technology Outlook 2006. Paris: OECD. Available on http://www.oecd.org .

Organization for Economic Co-Operation and Development (2005). Communications Outlook 2005. Paris: OECD. Available on http://www.oecd.org .

Poot, J., (2004), On the edge in the global economy. Cheltenham, U.K. and Northampton, Mass.: Elgar.

Pursiainen, H., (2003), Finnish telecom policy. Helsinki, Finland: Ministry of Transport and Communications Finland. Available on http://www.xn--viestintministerixqb56a.fi/oliver/upl750-Finnish\%20Telecom\%20Policy.pdf

Pursiainen, H., (2000), The 'Lazy Regulator' helps Finland's telecommunications boom. European Affairs 1(3), Summer 2000.

Spiller, P., \& Cardilli, C., (1997). The frontier of telecommunications deregulation: small countries leading the pack. Journal of Economic Perspectives 11(4), 127-38.

Tallberg,M.; Hämmäinen, H.; Töyli, J.: Kamppari, S. \& and Kivi, A. (2007). Impacts of handset bundling on mobile data usage: the case of Finland, Telecommunications Policy, vol. 31, pp. 648-659, 2007

Waverman, L., \& Sirel, E., (1997), European telecommunications markets on the verge of full liberalization. Journal of Economic Perspectives 11(4), pp 113-26.

Williamson, O., (1998), Transaction cost economics: how it works, where is it headed. De Economist 146(1) pp 23-58.

Williamson, O., (1979), Transaction cost economics: the governance of contractual relations. Journal of Law and Economics 22 October, pp 3-61.

Wilson, A., (1994), Wire and wireless: a history of telecommunications in New Zealand, 1860-1987. Palmerston North, New Zealand: Dunmore Press. 


\section{Figure 1. Relative Geography}
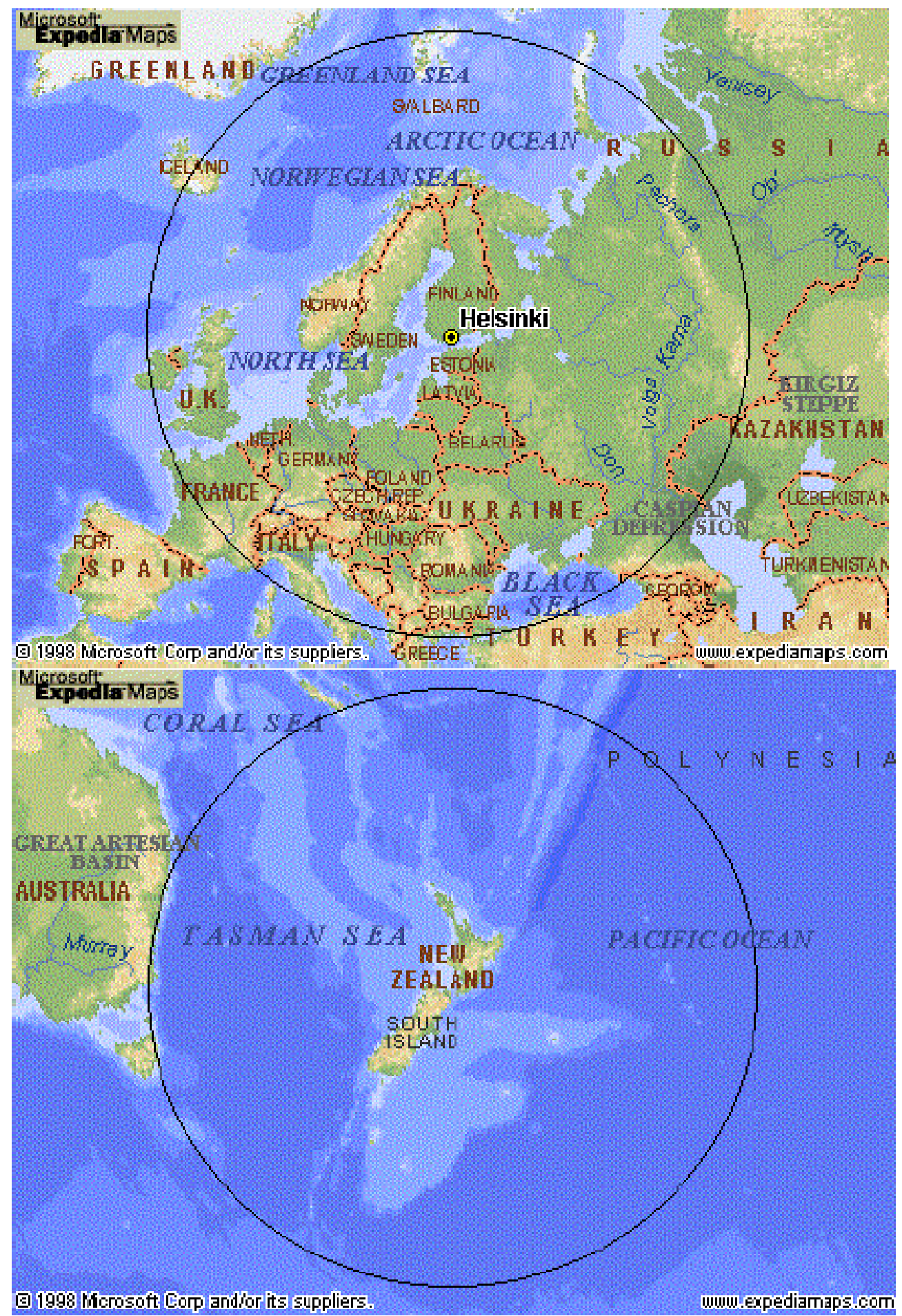

Source: Frame (2000:16-17) 
Figure 2. Comparative GDP Per Capita

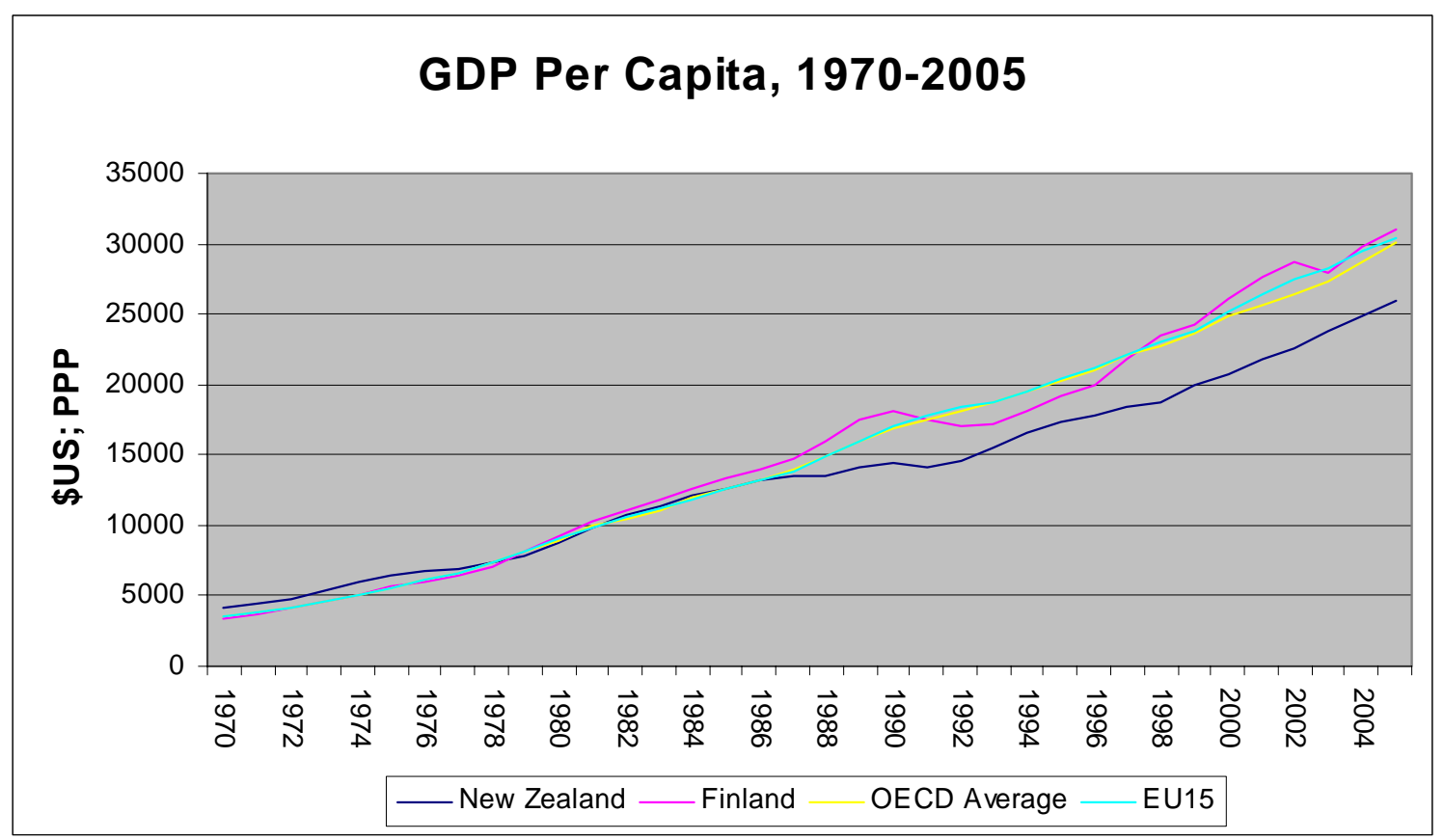

Source: OECD

Figure 3. Mobile Connection Consumption

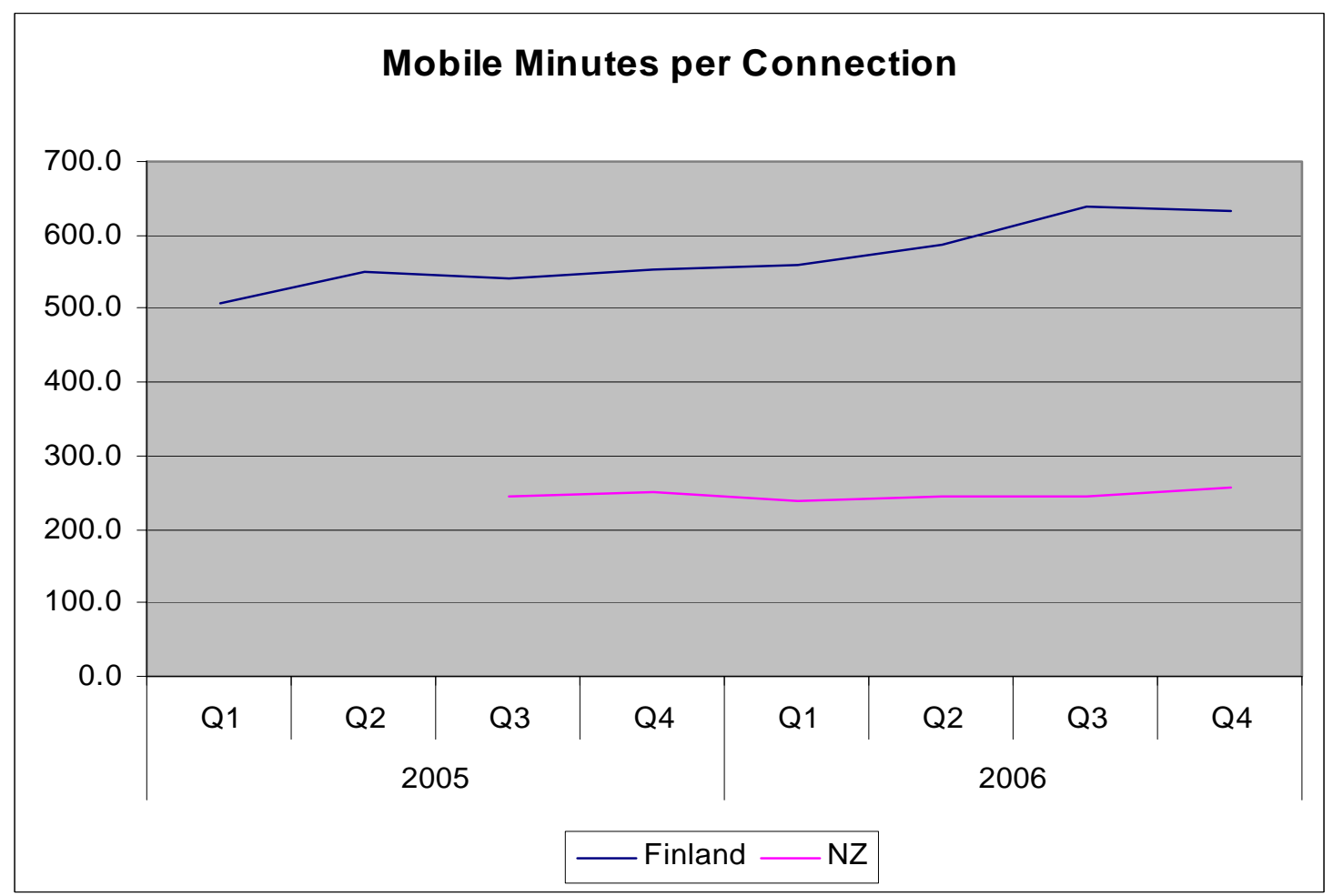

Source: Ficora (2006); Telecom Management Commentaries; Vodafone Quarterly Reports 
Figure 4. Fixed Line Consumption

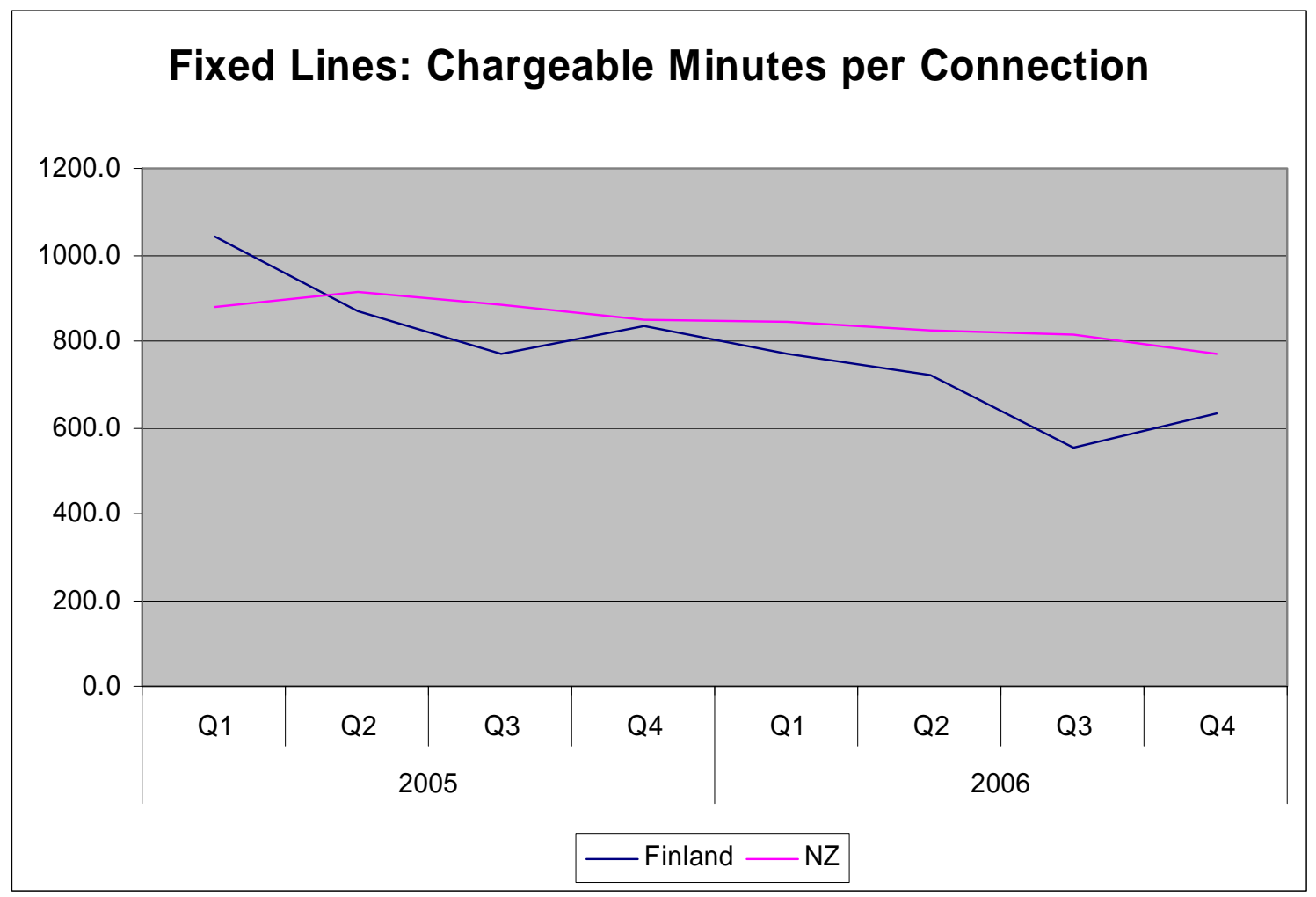

Source: Ficora (2006); Telecom Management Commentaries;

Figure 5. Telecommunications Sector Interaction

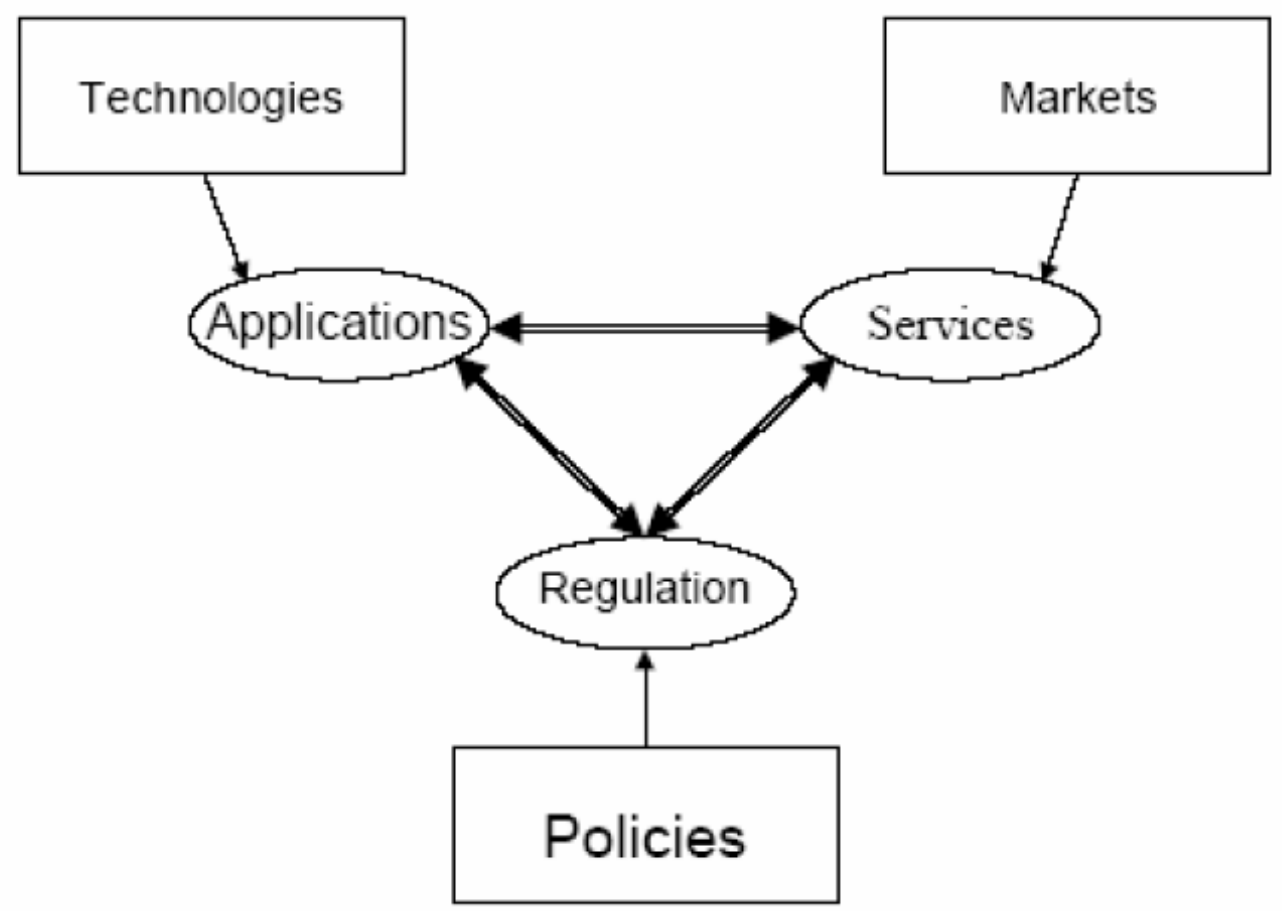

Source: Melody (2005:9) 
Table 1. Geographic, Demographic and Social Statistics

\begin{tabular}{|l|l|l|}
\hline & FINLAND & NZ \\
\hline Population (million) & 5.2 & 4.1 \\
\hline Land Area (sq km) & 338,145 & 270,050 \\
\hline Population Density per sq km & 16 & 15 \\
\hline Urbanisation & & \\
\hline Share in 10\% of regions with largest popns & 34 & 37 \\
\hline Variation in regional density (no. by sq km) & 195.18 & 237.15 \\
\hline max & 197.08 & 238.47 \\
\hline min & 1.89 & 1.31 \\
\hline OECD urbanisation indicator & 43 & 41 \\
\hline Life expectancy at birth 2004 & 78.8 & 79.2 \\
\hline males & 75.3 & 77 \\
\hline females & 82.3 & 81.3 \\
\hline Population Growth 1950-1990 (times) & 1.27 & 1.92 \\
\hline Foreign-born population \% (2004) & 3.3 & 18.8 \\
\hline Average unemployment \% 1995-2005 & 10.7 & 5.6 \\
\hline Road fatalities per million vehicles 2005 & 133.5 & 133.7 \\
\hline Road fatalities per million population 2005 & 72 & 99 \\
\hline Prison population per 100,000 population & 66 & 168 \\
\hline Municipal waste kg per capita 2003 & 450 & 400 \\
\hline SourC: Static New Zeand Stastcs & \\
\hline
\end{tabular}

Source: Statistics New Zealand; Statistics Finland and OECD Factbook

Table 2. ICT Uptake

\begin{tabular}{|l|c|c|}
\hline OECD Ranks & FINLAND & NZ \\
\hline Internet hosts per 1000 (2000) & 2 & 7 \\
Internet users per 100 (2005)(ITU) & 19 & 1 \\
\hline Secure servers per 1,000,000 (2000) & 10 & 4 \\
Secure Servers per 1000 (2006) & 13 & 4 \\
References to secure servers per 100 (2005) & 4 & 5 \\
\hline
\end{tabular}

Source: Howell (2003); OECD (2007)

Table 3. Comparison of Industry Sectors

\begin{tabular}{|l|c|c|}
\hline Industrial Characteristics & FINLAND & NZ \\
\hline Percentage of total value added (2002) & & \\
Agriculture, hunting, forestry, fishing & 3.3 & 7.0 \\
Industry (including energy) & 27.3 & 19.3 \\
Construction & 5.2 & 4.6 \\
Transport, hotels, restaurants & 22.6 & 23.1 \\
Banks, insurance, real estate & 20.4 & 28.1 \\
Business, government \& personal services & 21.2 & 17.9 \\
\hline
\end{tabular}

Source: Statistics New Zealand and Statistics Finland 
Table 4. Trade and ICT Statistics

\begin{tabular}{|l|c|c|}
\hline & FINLAND & NZ \\
\hline Share of trade in GDP ( \% 2005) & 39 & 29.1 \\
Share of ICT Manufacturing in value-added \% (2003) & 22.2 & 1.5 \\
ICT share of fixed capital formation \% (2002) & 26.6 & 19.6 \\
Exports of ICT equipment (\$US millions 2004) & 11,128 & 462 \\
Share telecoms in business value-added \% (2003) & 4.7 & \\
Share other ICT in business value-added \% (2003) & 6.5 & \\
\hline
\end{tabular}

Source: OECD (2005; 2006)

Table 5. Finnish Market Shares

\begin{tabular}{|l|c|c|}
\hline & $\mathbf{3 1 - 1 2 - 0 6}$ & $\mathbf{3 0 - 9 - 0 7}$ \\
\hline Fixed Line Subscriptions & $1,920,000$ & $1,750,000$ \\
Elisa & $32 \%$ & $33 \%$ \\
Sonera & $30 \%$ & $29 \%$ \\
Finnet group & $33 \%$ & $18 \%$ \\
DNA & & $16 \%$ \\
Other & $5 \%$ & $4 \%$ \\
\hline Mobile Subscriptions & $5,670,000$ & $5,960,000$ \\
Elisa & $38 \%$ & $39 \%$ \\
Sonera & $43 \%$ & $40 \%$ \\
Finnet group & $17 \%$ & $20 \%$ \\
DNA & $2 \%$ & $1 \%$ \\
Other & $1,428,000$ & $1,570,000$ \\
\hline Broadband Subscriptions & $34 \%$ & $33 \%$ \\
Elisa & $29 \%$ & $29 \%$ \\
Sonera & $25 \%$ & $15 \%$ \\
Finnet group & & $12 \%$ \\
DNA & $12 \%$ & $11 \%$ \\
Other & & \\
\hline
\end{tabular}

Source: Ficora (2006) and Finnet

http://www.finnet.fi/showattachment.asp?ID=338\&DocID=296 